\title{
Field test of the behavioral regulation of larval transport
}

\author{
Holly B. Kunze ${ }^{1, \mp}$, Steven G. Morgan ${ }^{2, *}$, Kamazima M. Lwiza ${ }^{1}$ \\ ${ }^{1}$ Marine Sciences Research Center, Stony Brook University, Stony Brook, New York 11794, USA \\ ${ }^{2}$ Bodega Marine Laboratory and Department of Environmental Science and Policy, University of California Davis, \\ Bodega Bay, California 94923, USA
}

\begin{abstract}
The maintenance of marine populations depends on the completion of larval migrations between adult and larval habitats, but the ability of microscopic larvae to regulate their movements in such a dynamic environment has been debated. Using a comparative hypothesis testing approach and intensive hourly sampling throughout the water column, we determined the ability of larvae of 6 species with different swimming abilities (2 gastropods, 2 crabs, 2 fishes) to overcome strong tidal mixing during spring tides and regulate their vertical, and hence, horizontal position, in opposing depth-stratified currents in the upper Hudson River estuary, USA. The vertical distributions of nonmotile eggs and swimming larvae generally differed, suggesting that larvae regulated depth. Eggs were passively mixed by tidal currents, but larvae typically aggregated in stratified portions of the water column, which fostered retention in the upper estuary. However, the capacity to regulate depth depended on swimming ability and the degree of mixing. In a predominantly mixed tidal environment upstream, mixing overcame most larvae when current velocities were maximal during mid-ebb or mid-flood tides; tidal vertical migrations were not evident for any species, and diel vertical migrations were apparent for only 1 species. In a partially stratified water column downstream, diel vertical migrations were apparent for larvae of 3 of 4 invertebrate species, and tidal vertical migrations were apparent for the 2 fish species. The presence of all larval stages showed that all species regulated depth sufficiently well to remain in the upper estuary. Regardless of swimming ability, larvae were retained in the estuary by occurring near the level of no net motion, even without completing tidal vertical migrations. Continuous profiling of larvae and hydrodynamics is necessary to reveal the ability of larvae to regulate depth in tidal mixing and recruit to adult populations.
\end{abstract}

KEY WORDS: Larval behavior $\cdot$ Vertical migration $\cdot$ Spawning $\cdot$ Eggs $\cdot$ Mixing $\cdot$ Advection

\section{INTRODUCTION}

Recruitment to marine populations depends on transport between adult and larval habitats (Morgan 2001, Strathmann et al. 2002). Because larvae typically cannot be tracked, transport is inferred from snapshots of the horizontal and vertical distributions of larval stages relative to current velocity and the parental habitat. A general model of larval transport in stratified estuaries has emerged by coupling these field surveys with laboratory studies of the responses of larvae to environmental stimuli, such as light, temperature, salinity, pressure, and turbulence (Epifanio 1988, Forward \& Tankersley 2001, Metaxas 2001, Queiroga \& Blanton 2005, Naylor 2006). Larvae are retained in estuaries despite net seaward flow by vertically migrating between currents that generally flow seaward near the surface and landward near the bottom or by remaining at mid-depth near the level of no net motion.

Historically, skeptics discounted the ability of larvae to effectively regulate depth in the field (e.g. 
DeWolf 1973). They argued that larvae remain in the same parcel of water over a tidal cycle, lacking changes in cues to stimulate tidal vertical migrations, and larvae drifting in open water do not have fixed visual or tactile references to judge speed and direction of water flow (McCleave \& Wippelhauser 1987). Furthermore, responses of larvae to isolated variables in static laboratory conditions and complexes of variables in the field do not always match (Cronin \& Forward 1986, Young 1986). Skeptics argued that a more parsimonious explanation for perceived tidal vertical migration is that turbulent mixing passively suspends larvae higher in the water column during flood tides and larvae settle lower in the water column near slack tide when mixing is minimal (DeWolf 1973). Depth regulation is believed to be much more difficult for weakly-swimming ciliated larvae, such as polychaetes and mollusks, than stronger-swimming larvae, such as crabs and fishes (Young 1995).

The crucial question is how well larvae are able to overcome displacement by vertical mixing from tidal currents and regulate their vertical, and thereby horizontal, positions in both stratified and mixed estuaries. If the vertical distributions of passive eggs and swimming larvae are similar, this suggests that turbulent mixing overcomes larvae; but periodic differences in their distributions would suggest that larvae regulate depth effectively (Fig. 1). If mixing is weak and the water column is stratified, then positively buoyant eggs should remain in the surface layer and negatively buoyant eggs should remain in the bottom layer. If vertical mixing is strong, then neutrally buoyant eggs should be distributed pas-

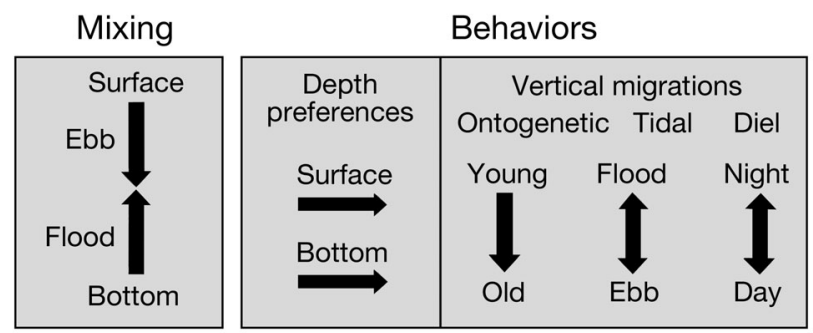

Fig. 1. Expected vertical distributions of passively mixed eggs and swimming larvae in estuaries. Left panel: positively buoyant eggs are mixed down from the surface by ebb tides, and negatively buoyant eggs are mixed up off the bottom by flood tides. Right panel: larvae of some species prefer surface waters, while others prefer bottom waters. Larvae also may undertake 3 types of vertical migrations: ontogenetic (descend late in development), tidal (descend during ebb tide and ascend during flood tide), and diel (ascend at night and descend during the daytime). Larvae of other species may undertake reverse vertical migrations, migrating in opposite directions sively throughout the water column, negatively buoyant eggs should be suspended by strong tidal currents and settle to the bottom during slack tides, and positively buoyant eggs should be mixed throughout the water column by tidal currents and float to the surface during slack tides. The following can be surmised regarding depth regulation: (1) larvae remaining in one portion of the water column throughout the tidal cycle is indicative of depth regulation; (2) ontogenetic behavior may be evident if young larvae occur higher in the water column than older larvae, (3) diel vertical migrations will be apparent if larvae are higher in the water column during night than day, and (4) tidal vertical migrations will be evident if larvae occur higher in the water column during flood than ebb tides. The time larvae spend in each part of the water column over the tidal cycle will affect transport; larvae that spend more time in outgoing surface currents or higher in the water column during ebb than flood tides will be transported downstream, those that primarily occur in bottom currents or higher in the water column during flood than ebb tides will be advected upstream, and those that remain near the interface of surface and bottom currents will experience little net transport.

Larval abundances oscillate during tidal and diel cycles and should be accounted for to correctly infer vertical movements of larvae. Ebb tides transport larvae from upstream locations and flood tides may return them, and vice versa, flood tides transport larvae to a study site from downstream and ebb tides may advect them back downstream (Islam et al. 2007, Hsieh et al. 2010, Kim et al. 2010). Furthermore, larvae arriving during early ebb or flood tides should be transported there from locations that are closer to the site than during late ebb or flood tides. These oscillations will be accompanied by changes in salinity and temperature as fresher, warmer water arrives from the upper estuary, or saltier, cooler water arrives from the lower estuary. Larvae may be more abundant during nocturnal tides when strong currents transport larvae to study sites in greater numbers and from farther away due to the diurnal inequality of the tides (Morgan 1995, Islam et al. 2007). Eggs and hatchlings may be especially abundant at night during peak spawning and hatching (Ferraro 1980, Morgan 1995).

We introduced a comparative hypothesis testing approach to better resolve the long-standing question of how well larvae regulate depth in the dynamic water column of estuaries (Young 1990). We compared the relationship between environmental condi- 
tions and the vertical distributions of negatively buoyant gastropod eggs and positively buoyant fish eggs, 2 weakly-swimming species of gastropod larvae, 2 moderately-swimming species of crab larvae, and 2 strongly-swimming species of fish larvae (Blaxter 1969, Hunter 1981, Chia et al. 1984). We also compared egg and larval distributions at sites with wellmixed and partially stratified water columns (see MacCready \& Geyer 2010 for review). Mixing, temperature, and salinity cycles were out of phase at 1 site, which enabled us to determine whether changes in vertical distributions of larvae coincided with mixing or temperature and salinity cycles. Sampling was conducted during spring tides when mixing is greatest, thereby providing a conservative test of larval swimming capabilities.

\section{MATERIALS AND METHODS}

\section{Study sites}

We conducted the study at 2 sites in the upper Hudson River estuary (New York, USA), which is partially mixed and controlled by 2-layer gravitational

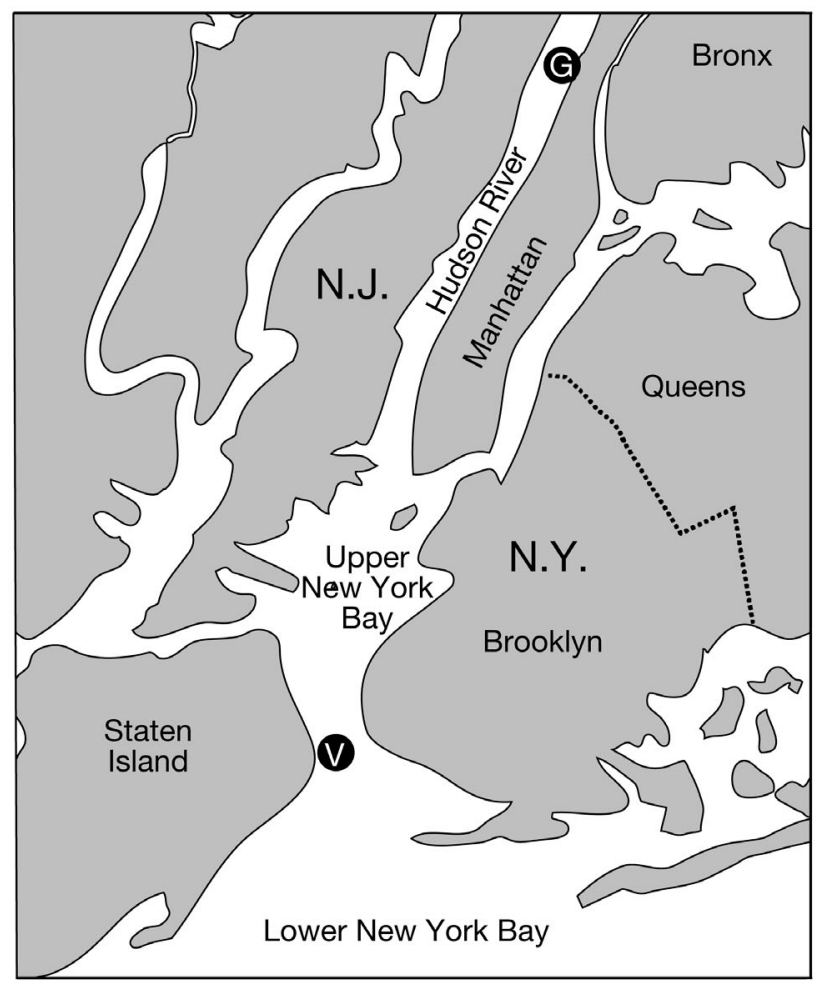

Fig. 2. Locations of the George Washington Bridge $\left(\mathrm{G}_{;} 16 \mathrm{~m}\right.$ depth) and Verrazano Narrows ( $V_{;} 26$ m depth) sites in the lower Hudson River estuary, New York, USA circulation and semidiurnal tides (Hunkins 1981). Study sties were located near the Verrazano Narrows (VZ) and George Washington (GW) bridges about 12.6 and $42 \mathrm{~km}$ from the entrance to the lower bay of New York Harbor, respectively (Fig. 2). The VZ and GW sites were located on the western and eastern margins, respectively, of a navigational channel that extends to the mouth of the lower bay. The VZ site was located in $26 \mathrm{~m}$ of water at a $1.2 \mathrm{~km}$ wide constriction between the upper and lower bays of the harbor, and the GW site was located upstream of the upper bay in a $1 \mathrm{~km}$ wide section of the Hudson River that was about $16 \mathrm{~m}$ deep.

The study was conducted in 1992 during July, when the Hudson River discharges about $250 \mathrm{~m}^{3} \mathrm{~s}^{-1}$ of freshwater (Abood 1977). Salinity usually varies little across the estuary at the 2 study sites (Parker et al. 1976, Hunkins 1981). Tides resemble a progressive wave in which high water occurs soon after maximum flood velocities (Chant \& Wilson 2000). Near the end of ebb tide, a bottom gravity current front advances upstream leaving a mixed bottom layer and a sharpened halocline with high velocity shears (Chant \& Wilson 2000). Later during flood tide, the halocline is elevated and a velocity jet typical of a salt wedge estuary develops near the halocline (Geyer \& Farmer 1989, Jay \& Smith 1990, Chant $\&$ Wilson 2000). Bottom stratification develops during ebb tide, and the upper water column is mixed by maximum ebb currents. Although mixing increases during spring ebb tides (Peters 1995), a velocity jet still forms near the halocline during flood tide (Chant \& Wilson 2000).

\section{Study species}

Larvae of several species were sampled, including periwinkle Littorina littorea, slipper shell Crepidula fornicata, mud crabs Rhithropanopeus harrisii and Dyspanopeus sayi, bay anchovy Anchoa mitchilli, and naked goby Gobiosoma bosc. Larvae of these species have different swimming capabilities. Adults of these species are abundant at both sites, except $R$. harrisii, which is common only at the GW site, and $D$. sayi, which is common only at the VZ site. Eggs of $L$. littorea and fishes were also abundant in the water column at both sites. Most of the fish eggs collected were spawned by A. mitchilli. G. bosc attaches its eggs to the substrate (Dahlberg \& Conyers 1973, Fahay 1983), and therefore eggs of the second most abundant constituent of the ichythoplankton were not collected. 
Crepidula fornicata and Littorina littorea commonly occur from brackish to saline waters but they are most abundant at higher salinities (Wells 1965, Dahlberg \& Conyers 1973, Hardwick-Witman \& Mathieson 1983, Bauer et al. 1995). Peak spawning by both species occurs at night during spring tides and new and full moons (Chipperfield 1951, Newell \& Newell 1973, Fish 1979, Alifierakis \& Berry 1980, Todd \& Laverack 1991). Eggs of L. littorea are released into the water column and hatch as veligers 1 to 2 wk later (Newell \& Newell 1973, Fish 1979, Todd \& Laverack 1991). L. littorea larvae grow from 180 to $600 \mu \mathrm{m}$ in shell length (Newell \& Newell 1973, Fish 1979) before settling to the substrate 2 to $6 \mathrm{wk}$ later (Fretter \& Graham 1962, Williams 1984, Newell \& Newell 1973). Larvae of C. fornicata are larger than those of $L$. littorea, and grow from 235 to $2300 \mu \mathrm{m}$ in shell length before settling from the water column about 3.5 wk later (Chipperfield 1951, Newell \& Newell 1973, Pechenik 1984, Pechenik \& Lima 1984, Lima 1987). Gastropod veligers swim at about $0.13 \mathrm{~cm} \mathrm{~s}^{-1}$ (Chia et al. 1984).

Rhithropanopeus harrisii primarily live in brackish waters of upper estuaries, and Dyspanopeus sayi commonly live in polyhaline waters of mid- to lower estuaries (Sandifer 1975, Williams 1984). Both crabs release larvae at night; however, $R$. harrisii release larvae daily and $D$. sayi may release larvae more often during spring tides (DeVries \& Forward 1989, Hovel \& Morgan 1997). Both crabs molt through 4 larval instars in about 10 to $15 \mathrm{~d}$ and then metamorphose to megalopae that settle into adult habitats about 5 d later (Williams 1984). R. harrisii larvae are transported downstream from brackish waters where they are released, but most of them develop in salinities less than 25 (Bousfield 1955, Sandifer 1975, Cronin 1982). D. sayi larvae develop in lower estuaries and occasionally occur on adjacent inner continental shelves (Sandifer 1975, Morgan 2005). Larvae and megalopae of both species appear to undertake diel and tidal vertical migrations (Cronin \& Forward 1986, DeVries et al. 1994, Schell 1996). Larvae and megalopae of both species swim vertically in response to salinity, temperature, pressure, and light at 0.3 to $1.1 \mathrm{~cm} \mathrm{~s}^{-1}$ (Cronin \& Forward 1986, Forward 1989, DeVries et al. 1994). Megalopae of both crabs occur lower in the water column than do larvae (Cronin 1982, Cronin \& Forward 1986, DeVries et al. 1994, Schell 1996, Christy \& Morgan 1998).

Anchoa mitchilli are euryhaline and occur throughout estuaries (Houde \& Zastrow 1991). This species spawns nightly in salinities of 10 to 20 and temperatures of 15 to $30^{\circ} \mathrm{C}$, and larvae hatch the next night
(Wheatland 1956, Wang \& Kernehan 1979, Dovel 1981, Matarese \& Sandknop 1983, Zastrow et al. 1991). In the Hudson River estuary, A. mitchilli eggs are most abundant near our study sites, where they are spawned, and most larvae occur farther upstream indicating that larvae migrate to the upper Hudson River estuary (Dovel 1981). Similar distributions of eggs and larvae have been described in Delaware Bay (Wang \& Kernehan 1979). Larvae and juvenile stages may develop in as little as $2.5 \mathrm{mo}$, although most of them will overwinter before maturing the following year (Houde \& Zastrow 1991, Zastrow et al. 1991). Most fish larvae swim 2 to 3 body lengths $\mathrm{s}^{-1}$, and swimming speed of anchovy larvae increases from about $0.2 \mathrm{~mm} \mathrm{~s}^{-1}$ to $2.3 \mathrm{~cm} \mathrm{~s}^{-1}$ during development (Blaxter 1969, Hunter 1981).

Gobiosoma bosc inhabits oyster reefs from brackish to saline waters (Dahlberg \& Conyers 1973). These fish spawn when water temperatures reach 16 to $20^{\circ} \mathrm{C}$ (Dahlberg \& Conyers 1973, Dovel 1981). Larvae hatch at night in mid- to lower estuaries, rise from the substrate and descend low in the water column 10 h later (Massmann et al. 1963, Fahay 1983). Diel vertical migrations are also evident in older larvae and postlarvae (Wang \& Kernehan 1979). Like Anchoa mitchilli, most larvae occur in upper estuaries, suggesting that they are transported there from spawning areas downstream (Massmann et al. 1963, Wang \& Kernehan 1979). Larvae 12 to $15 \mathrm{~mm}$ long school near the bottom and settle in shallow oyster beds (Breitburg 1989).

\section{Sampling}

Intensive physical and biological sampling is required to determine whether larvae effectively regulate depth or are passively mixed by tidal currents. We sampled frequently throughout the water column over consecutive tidal and light-dark cycles at the 2 study sites to determine whether vertical distributions of eggs and larvae changed periodically with temperature and salinity every $12 \mathrm{~h}$, and light levels every $24 \mathrm{~h}$. The 2 study sites were sampled for $48 \mathrm{~h}$ each during spring tides in July 1992. Although it was beyond our means to sample the 2 sites simultaneously, they were sampled during consecutive spring tides (15 to 17 July and 29 to 31 July at the VZ and GW sites, respectively) to minimize variation in the physical environment and larval abundances.

The vessel was triple-anchored to enable continuous physical and biological sampling of the passing water column, over 4 tidal and 2 diel cycles at each site. 
Salinity, temperature, current velocity, and light were profiled every $30 \mathrm{~min}$ at $1 \mathrm{~m}$ intervals using an Interocean S4 current meter, a CTD (Applied Microsystems, Model STD12), and a dual surface and underwater photosynthetically active radiation (PAR) meter. A high-capacity plankton pump and suction hose $(7.6 \mathrm{~cm}$ diameter) were used to continuously sample eggs and larvae from 4 discrete depths as determined by water column structure. When the water column was stratified, samples were taken 1 to $3 \mathrm{~m}$ below the surface, immediately above and below the halocline and $1.5 \mathrm{~m}$ above the bottom; when the water column was well mixed, sampling depths were evenly spaced. Each depth was sampled sequentially for $10 \mathrm{~min}$ from the bottom to the top of the water column while $6000 \mathrm{l}$ of water were filtered through a series of 3 nets to exclude large organisms and debris $11 \mathrm{~cm}$ mesh) while collecting crab, fish, and large gastropod larvae (335 $\mu \mathrm{m}$ mesh), and small gastropod larvae and eggs $(153 \mu \mathrm{m})$. Hoses were cleared for several minutes between samples. Plankton samples were fixed with $1 \%$ formaldehyde, and a Folsom plankton splitter was used to subsample dense samples.

Crab larvae were identified to developmental stage. Crepidula fornicata larvae range from 235 to $2300 \mu \mathrm{m}$ in shell length (Lima 1987) and were divided into 2 sizes classes: small, newly hatched $(<335 \mu \mathrm{m})$ and larger, older $(>335 \mu \mathrm{m})$ larvae. Most fish larvae were preflexion stage and had not yet developed functioning swim bladders.

\section{Data presentation and analysis}

Profiles of salinity, temperature, alongstream current velocity, and mixing were contoured to characterize the physical environment of each study site. The degree of mixing was determined by calculating the Richardson number $\left(\mathrm{R}_{\mathrm{i}}\right)$. Stratification overcomes turbulent mixing at $R_{i} \geq 0.25$, and turbulent mixing overcomes stratification at $R_{i}<0.25$. $R_{i}$ was calculated from velocity and density profiles:

$$
\mathrm{R}_{\mathrm{i}}=\frac{N^{2}}{\left(\frac{\partial u}{\partial z}\right)^{2}+\left(\frac{\partial v}{\partial z}\right)^{2}}
$$

where $N^{2}=-\frac{g}{\rho} \frac{\partial \rho}{\partial z}$ is the buoyancy frequency, $g=$ gravity, $\rho=$ density, $z=$ depth,$u=$ velocity along the axis of the estuary, and $v=$ velocity across the estuary.

The mean depth of center of mass (ZCM) and standard error were calculated for fish and Littorina litto- rea eggs and all larvae during each sampling period. The similarity in the mean depth distributions of eggs and larvae over the $48 \mathrm{~h}$ studies at each site was tested using Pearson's correlation.

Shifts in vertical distributions of eggs and larvae relative to tidal and diel cycles was best visualized by overlaying bubble plots of their concentrations on contours of the physical environment. Simply lumping data into categories and reporting means and standardized errors independently of physical data masks the dynamic relationship between egg and larval distributions relative to water column structure over tidal cycles. Using means and standard errors is sufficient to depict periodic vertical migrations but is not sufficient to distinguish depth regulation from vertical mixing by tidal currents in highly dynamic, shallow estuaries. Current velocity contours were used as a background for egg and larval abundances at the predominately mixed GW site to illustrate the close association between this variable and distributions and abundances of eggs and larvae. Salinity contours were used as a background for egg and larval abundances at the more stratified VZ site, because salinity, temperature, velocity and mixing cycles all occurred in phase and because salinity is most often suggested to cue vertical swimming by larvae. Profiles of each larval stage or size class are presented even when they are similar to emphasize the repeatability of the patterns of turbulent mixing and depth regulation.

We partitioned the water column into 4 depth bins before analyzing egg and larval abundances relative to depth, tidal phase, and diel phase. At the GW site, the surface, mid-surface, mid-bottom, and bottom bins were defined as occurring from $0-4,5-8,9-12$, and 13-16 m, respectively. At the VZ site, the 4 bins occurred at $0-6,7-12,13-18$, and 19-26 m. For each depth bin, slack tide was defined as ranging from -30 to $+30 \mathrm{~cm} \mathrm{~s}^{-1}$, flood tide as $>30 \mathrm{~cm} \mathrm{~s}^{-1}$, and ebb tide as $<-30 \mathrm{~cm} \mathrm{~s}^{-1}$. Flood and ebb tides then were divided into 2 equal periods, early and late, resulting in a total of 6 categories: early flood, late flood, slack after flood, early ebb, late ebb, and slack after ebb. Because few fish were collected, statistical power was increased by partitioning the tidal cycle into only 4 phases: flood, slack after flood, ebb, and slack after ebb. Periods of light and dark were based on light intensity near the surface.

Egg and larval abundances were log transformed to meet assumptions, and a 3-way ANOVA relative to depth, tidal phase, and diel phase was conducted for each taxonomic category. Larvae regulated depth in tidal mixing if terms including depth were significant: (1) depth indicates a depth preference, (2) 
depth $\times$ tide interaction indicates a tidal vertical migration, and (3) depth $\times$ diel interaction indicates a diel vertical migration. Nonsignificant interaction terms were removed and data were reanalyzed to increase statistical power. Multiple regressions determined whether larval distributions were related to temperature, salinity, or current velocity, and $t$-tests revealed whether eggs and larvae of each taxonomic category were more abundant at the GW than at the VZ site. The direction of transport for each taxonomic category was inferred from its relative abundance and vertical distribution during each phase of the tidal cycle, profiles of residual flow from Heilman (1995), and horizontal distributions of larvae.

\section{RESULTS}

\section{Physical environment}

At the GW site, cold saline water intruded along the bottom and mixed higher in the water column until surface waters began to flood (Fig. 3). Maximum flood current occurred as a velocity jet formed near the pycnocline, which developed near the bottom during maximum flood tide and moved midway into the water column by the end of flood tide. Maximum salinity and minimum temperature occurred throughout the water column several hours after maximum flood velocity during slack after flood tide. Maximum ebb tide velocity occurred near the surface, and the lowest salinity and highest temperature occurred during slack after ebb tide near the surface. The entire water column generally was mixed more than half of the time, and maximal turbulent mixing occurred during flood tide when cool saline water mixed from the bottom into the lower water column. The water column was stratified at mid-depth from maximum flood tide until slack after flood, and it was thoroughly mixed during ebb tide when low salinity surface waters mixed throughout the shallow $(16 \mathrm{~m}$ deep) water column. PAR was not detected deeper than $2 \mathrm{~m}$ below the surface.

The water column was deeper $(26 \mathrm{~m})$, cooler, saltier, and more stratified at the VZ than at the GW site (Fig. 4). Maximum salinity and minimum temperature occurred in the lower water column just after maximum flood tide, which occurred just below the pycnocline midway in the water column. During ebb tide, maximum velocity, minimum salinity, and maximum temperature occurred at the surface. The water column was stratified during late flood and late ebb tides through slack tides, especially during cooler
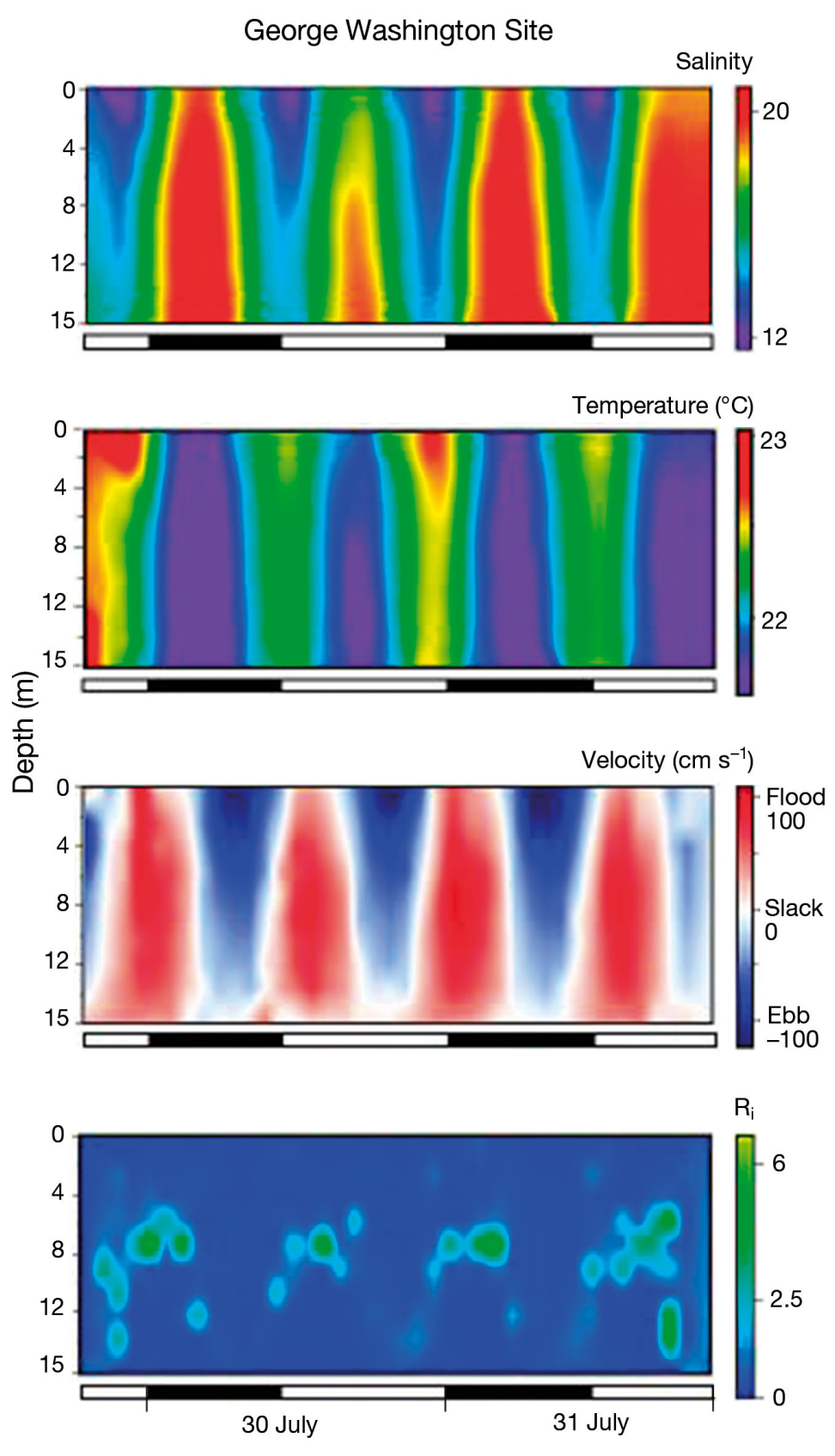

Fig. 3. Contours of salinity, temperature, velocity, and Richardson number $\left(\mathrm{R}_{\mathrm{i}}\right)$ at the George Washington Bridge site in the Hudson River estuary for 48 h from 29 to 31 July 1992. Open and solid bars below the horizontal axes represent daylight and darkness, respectively. Negative current velocities indicate seaward flow, positive values indicate upstream flow, and velocities between -30 and $+30 \mathrm{~cm} \mathrm{~s}^{-1}$ represent slack water (white). Dark areas extending downward from the surface represent ebb conditions, and those extending upward from the bottom (temperature, salinity) or centered at mid-depth (velocity) represent flood currents. $\mathrm{R}_{\mathrm{i}}$ values $<$ and $>0.25$ indicate stratified and mixed regions of the water column, respectively. The water column is $1 \mathrm{~m}$ deeper than shown 

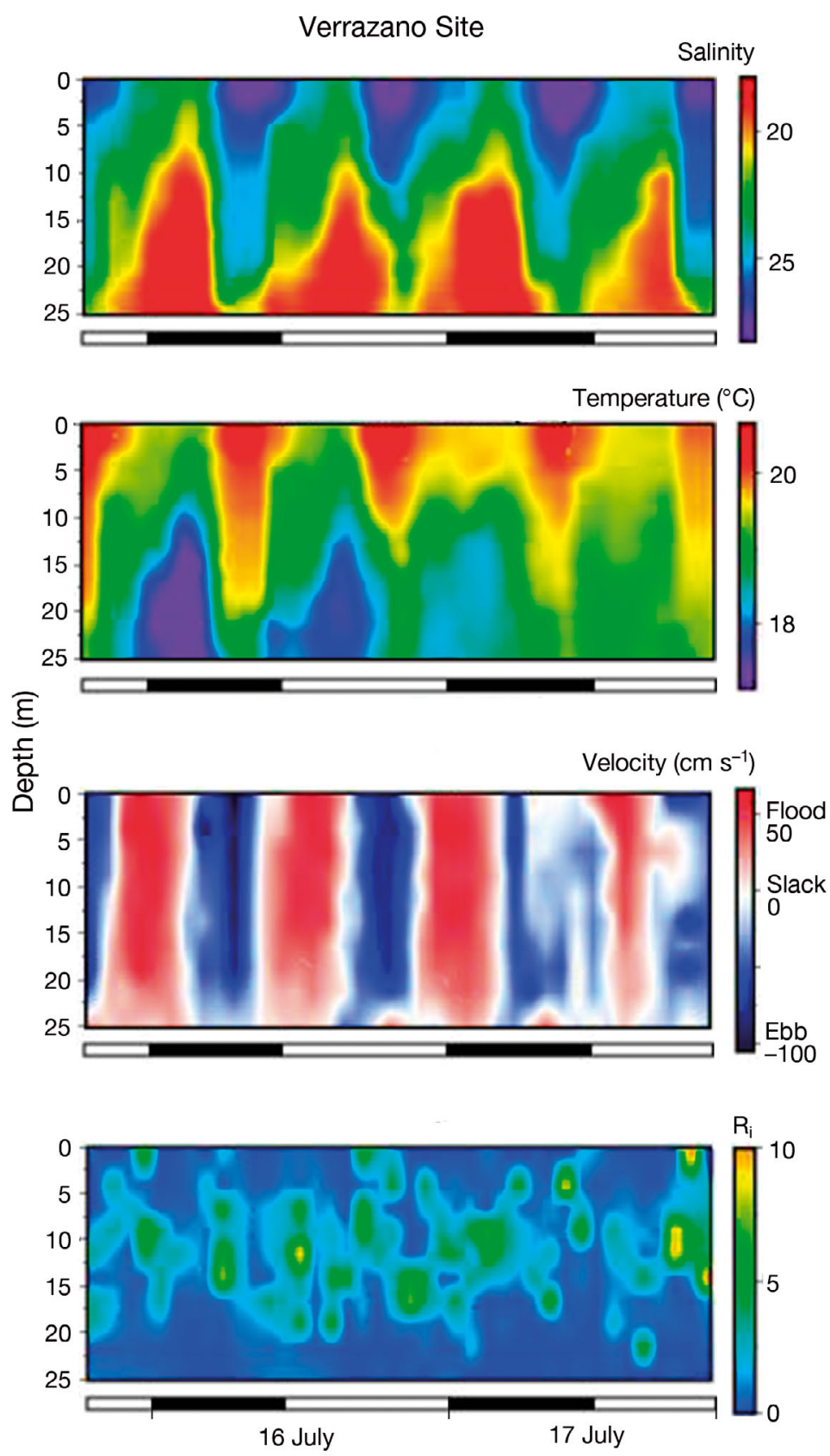

Fig. 4. Contours of salinity, temperature, velocity, and Richardson number $\left(\mathrm{R}_{\mathrm{i}}\right)$ at the Verrazano Narrows site in the Hudson River estuary for $48 \mathrm{~h}$ from 15 to 17 July 1992. See Fig. 3 for details

evening hours, and it was mixed during the rest of the tidal cycle. Greatest mixing occurred when velocities were maximal in the lower water column during flood tide and near the surface during ebb tide. An eddy formed during the last $8 \mathrm{~h}$ of sampling, resulting in a decrease in along-stream flow, an increase in cross-stream flow, decreased stratification during slack after ebb tide, and smaller oscilla- tions in temperature and salinity than were previously observed during this portion of the tidal cycle. PAR was not detected below $4 \mathrm{~m}$ depth.

\section{Relationships between depth distributions of eggs and larvae}

The ZCM of passive eggs and swimming larvae generally differed during the $48 \mathrm{~h}$ sampling periods at both study sites, indicating that larvae of most species were not simply mixed throughout the water column by tidal currents. At the mixed GW site, the ZCM of fish eggs and larvae were not correlated, and Littorina littorea eggs were correlated only with weakly-swimming small $(<335 \mu \mathrm{m})$ Crepidula fornicata larvae $\left(\mathrm{r}^{2}=0.08, \mathrm{p}=0.04\right)$ and their own larvae $\left(r^{2}=0.28, p<0.001\right.$; Fig. 5). At the partially stratified VZ site, the ZCM of fish eggs and Littorina eggs were not correlated with any of the larvae (Fig. 6).

\section{Vertical distributions relative to environmental cycles}

\section{Eggs}

Fish eggs occurred throughout the comparatively shallow water column at the GW site where they were neutrally buoyant and mixed by tidal currents (Figs. $5 \&$ 7, and see Tables S1 \& S2 in the supplement at www.int-res.com/articles/suppl/m000p071_ supp.pdf). They were especially abundant during slack after flood tide at night in cool water, gradually declined during the daytime, and were least abundant during slack after ebb tide, indicating that most of them were transported downstream after being spawned. Fish eggs were more abundant downstream at the VZ site, where they primarily occurred near the surface during ebb tides in warm water at night, further indicating that they arrived from upstream (Figs. 6 \& 7; Tables S1-S3 in the supplement). They were 2 orders of magnitude more abundant than Anchoa mitchilli larvae at both study sites due to downstream transport or mortality.

Negatively buoyant eggs of Littorina littorea were mixed from the bottom throughout the water column at the GW site, but they were most abundant in the upper water column during ebb tides (Figs. 5 \& 7; Tables S1 \& S2). They were most abundant when the water column was well mixed, especially during nocturnal ebb tides, and they were least abundant during slack tides. Hence, they were mixed from the 

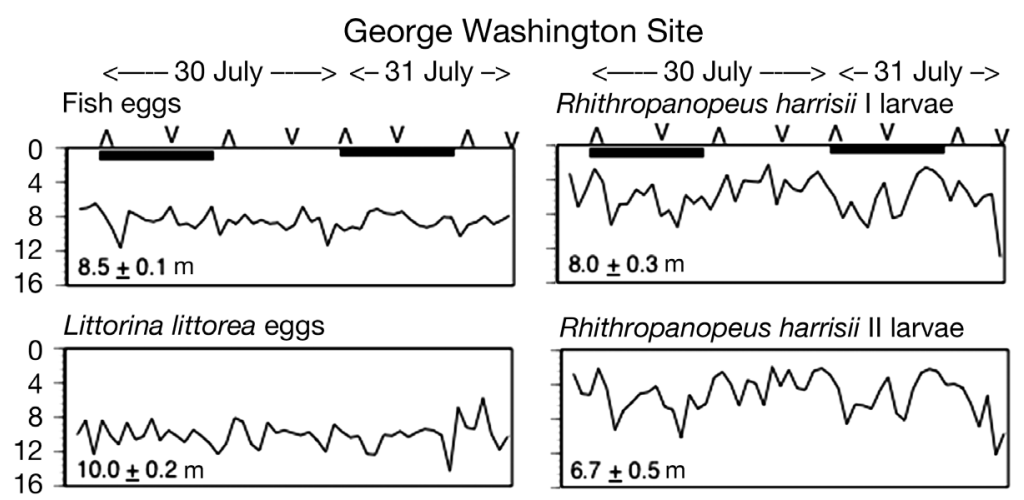

Rhithropanopeus harrisii II larvae
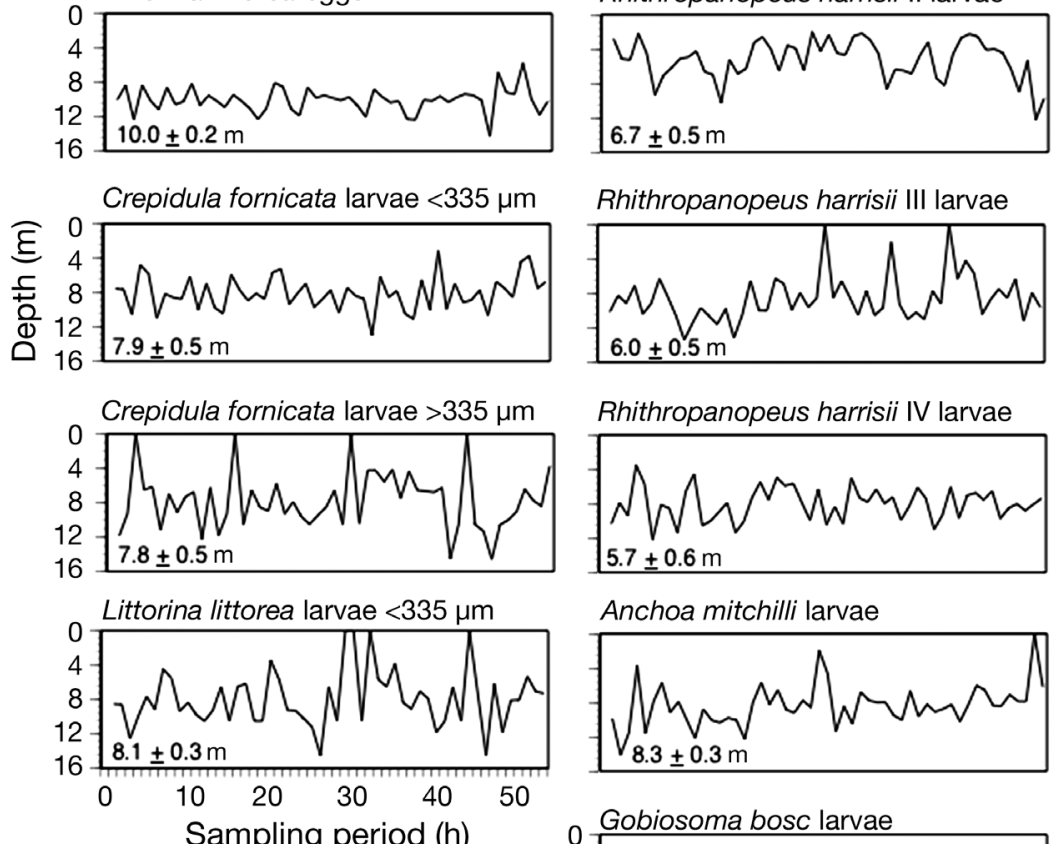

Sampling period (h)

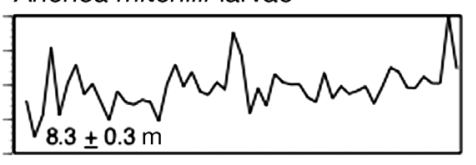

Rhithropanopeus harrisii III larvae

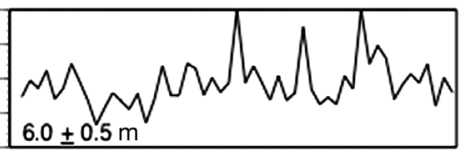

Rhithropanopeus harrisii IV larvae

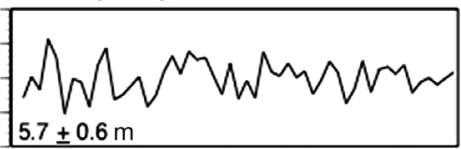

Anchoa mitchilli larvae

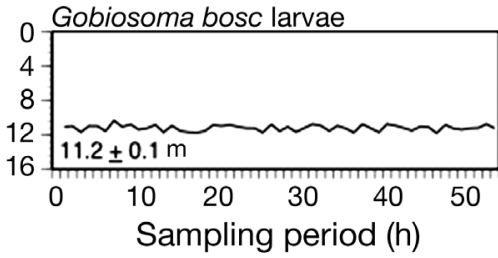

Fig. 5. Mean depth of center of mass (ZCM) of eggs and larvae sampled hourly from 29 to 31 July 1992 at the George Washington bridge site. The overall ZCM $( \pm \mathrm{SE}$ ) for each species or group is reported in the lower left corner. Open and solid bars along top horizontal axes represent daylight and darkness. $(\wedge)$ : high slack tides; $(\vee)$ : low slack tides

bottom during flood and ebb tide, and they settled from the water column during slack tides. They were an order of magnitude more abundant downstream at the VZ site where they were most abundant near the bottom from flood through slack after flood tides in well-mixed, cool, saline water (Figs. 6 \& 7; Tables S1-S3). They were mixed off the bottom during flood tides, settled to the bottom during slack after flood tide, and remained there through ebb tide.

\section{Gastropod larvae}

Tidal, diel, and ontogenetic vertical migrations were not evident for Crepidula fornicata at the
GW site (Figs. 5,\& 8; Tables S1-S3). Both small and large larvae $(<$ and $>335 \mu \mathrm{m}$, respectively) occurred throughout the water column near slack after flood tide, when salinity was 21 , and they were uncommon during all other phases of the tidal cycle. Hence, C. fornicata larvae were uncommon at the GW site until they arrived on late flood tides in saline water from downstream, where they were 2 orders of magnitude more abundant.

At this time, the entire water column was flooding and larvae were transported into the study area at all depths. Shortly thereafter, larvae were advected back downstream by ebb currents. Small Crepidula fornicata larvae were more abundant during nighttime than daytime, and large larvae were most abundant during nocturnal high slack tides. Larvae may have been more abundant at night because stronger flood currents would have transported larvae into the study area from farther downstream than during the daytime due to the diurnal inequality in the tides.

Both small and large Crepidula fornicata larvae primarily occurred in stratified waters near mid-depth at the VZ site (Figs. 6 \& 9; Tables S1 \& S2). Small larvae occurred in the upper half of the water column during flood tides, and they were mixed throughout the water column by ebbing surface currents. Tidal vertical migrations were not apparent because most larvae did not occur low in the water column during ebb tide. Diel vertical migrations were evident because small larvae were common at the surface at night but rarely occurred there during the daytime. Small C. fornicata larvae were most abundant during late ebb tides at night in strong ebb currents, suggesting that more of them were transported to the VZ site from upstream than downstream locations. Large $C$. fornicata larvae were most abundant from late ebb through early flood tide throughout the light-dark cycle, indicating that there was little net transport of these larvae at the VZ site. Indeed, the presence of both small and large larvae at the 2 study sites indicates that larvae were retained in the estuary. 
Verrazano Site
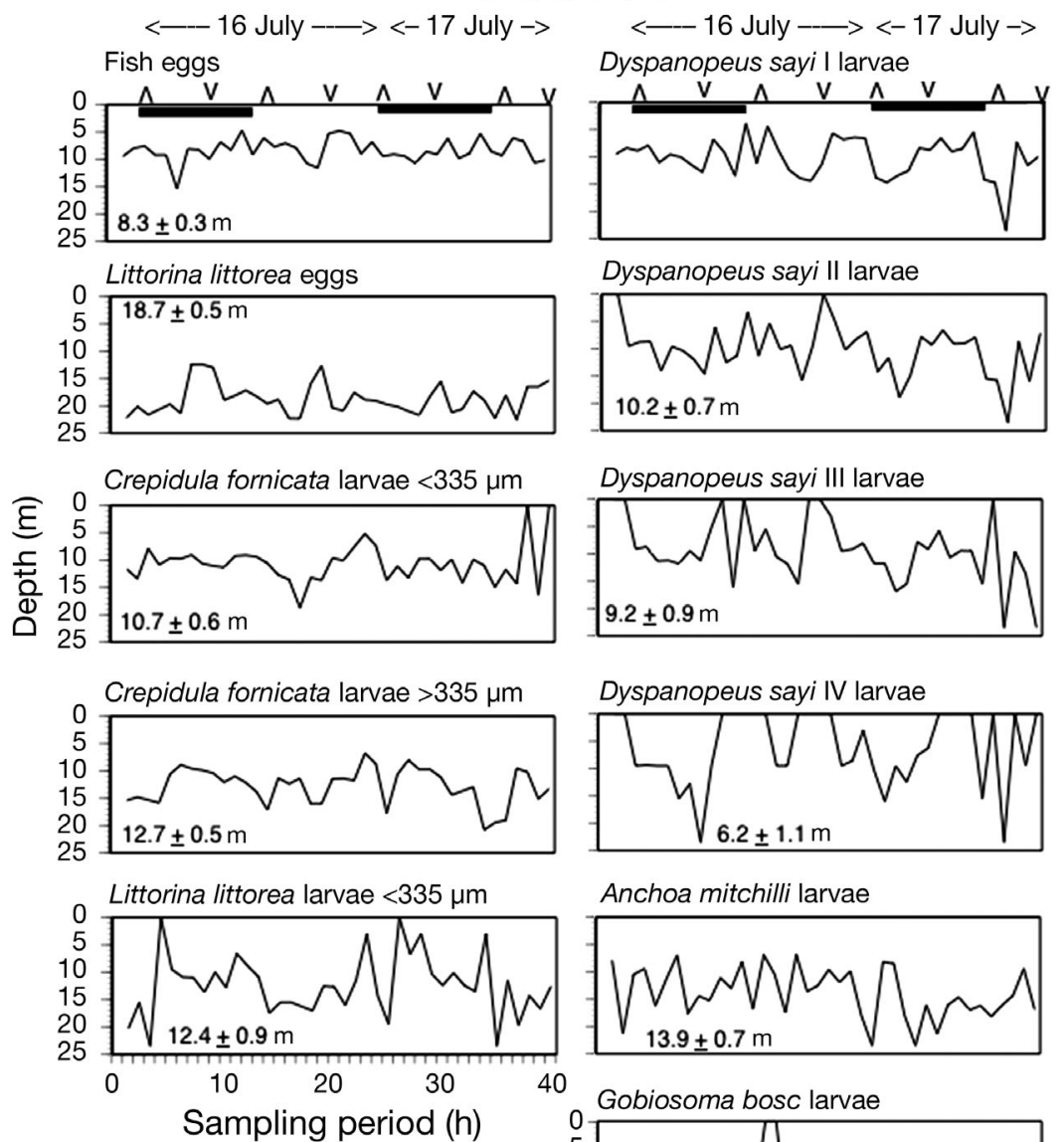

Anchoa mitchilli larvae

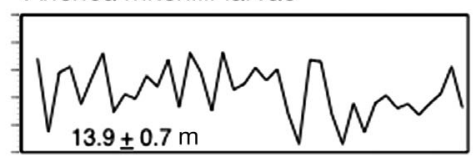

0

Gobiosoma bosc larvae

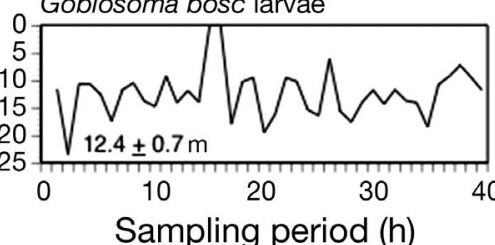

Fig. 6. Mean depth of center of mass (ZCM) of eggs and larvae sampled hourly from 15 to 17 July 1992 at the Verrazano Narrows site. See Fig. 5 for details

Littorina littorea larvae were most abundant in stratified waters at mid-depth during flood tides at the GW site, indicating that they were transported there in the velocity jet from nearby downstream locations during early flood tides and more distant locations during late flood tides (Figs. 5 \& 8; Tables $\mathrm{S} 1 \& \mathrm{~S} 2)$. However, larvae also were common during ebb tides, suggesting that they were transported to the study site from upstream. Although tidal vertical migrations were not apparent, diel vertical migrations were evident; larvae were abundant in surface waters at night rather than during the daytime.

Neither tidal nor diel vertical migrations were apparent for Littorina littorea larvae at the VZ site (Figs. 6 \& 9; Tables S1-S3). Larvae were most abundant from ebb to early flood tides. Larvae were delivered to this site by both flood and ebb currents, and consequently were distributed throughout the water column rather than at mid-depth near the flood-tide velocity jet. Although more $L$. littorea eggs were collected at the VZ site, larvae were an order of magnitude more abundant upstream at the GW site. Therefore, larvae were retained in the estuary despite the lack of tidal and diel vertical migrations. L. littorea eggs were an order of magnitude more abundant than L. littorea larvae at both sites.

Crab larvae

Rhithropanopeus harrisii larvae occurred at the GW site in stratified, low-salinity waters at mid-depth during flood tides, where the velocity jet transported them upstream in cool high-velocity flood currents (Figs. 5 \& 10; Tables S1 \& S2). The association with the velocity jet became stronger during development, as $R$. harrisii larvae became more abundant toward the end of flood tide, when flood velocities were maximal and temperatures were minimal. First-stage larvae were abundant throughout ebb tides, indicating that they were transported to the study site from upstream. However, they were most abundant near the onset of flood tides, suggesting that many of them were transported back upstream to the study site. They were least common toward the end of flood tide, suggesting that fewer of them were transported there from far downstream. By the second stage, larvae were uncommon during ebb tides, indicating that most of them now occurred downstream of the study site. Because more larvae were collected toward the end of flood tide late in development, more larvae arrived at the study site from farther downstream. All larval stages rose in the water column together with the intruding bottom current as flood tide progressed, and then they were mixed throughout the water column by ebb currents, although this pattern was not significant for the few fourth-stage larvae collected. Although rising in the water column during flood tides is consistent with tidal vertical migration, the occurrence of larvae throughout the water column during ebb tides is not. 


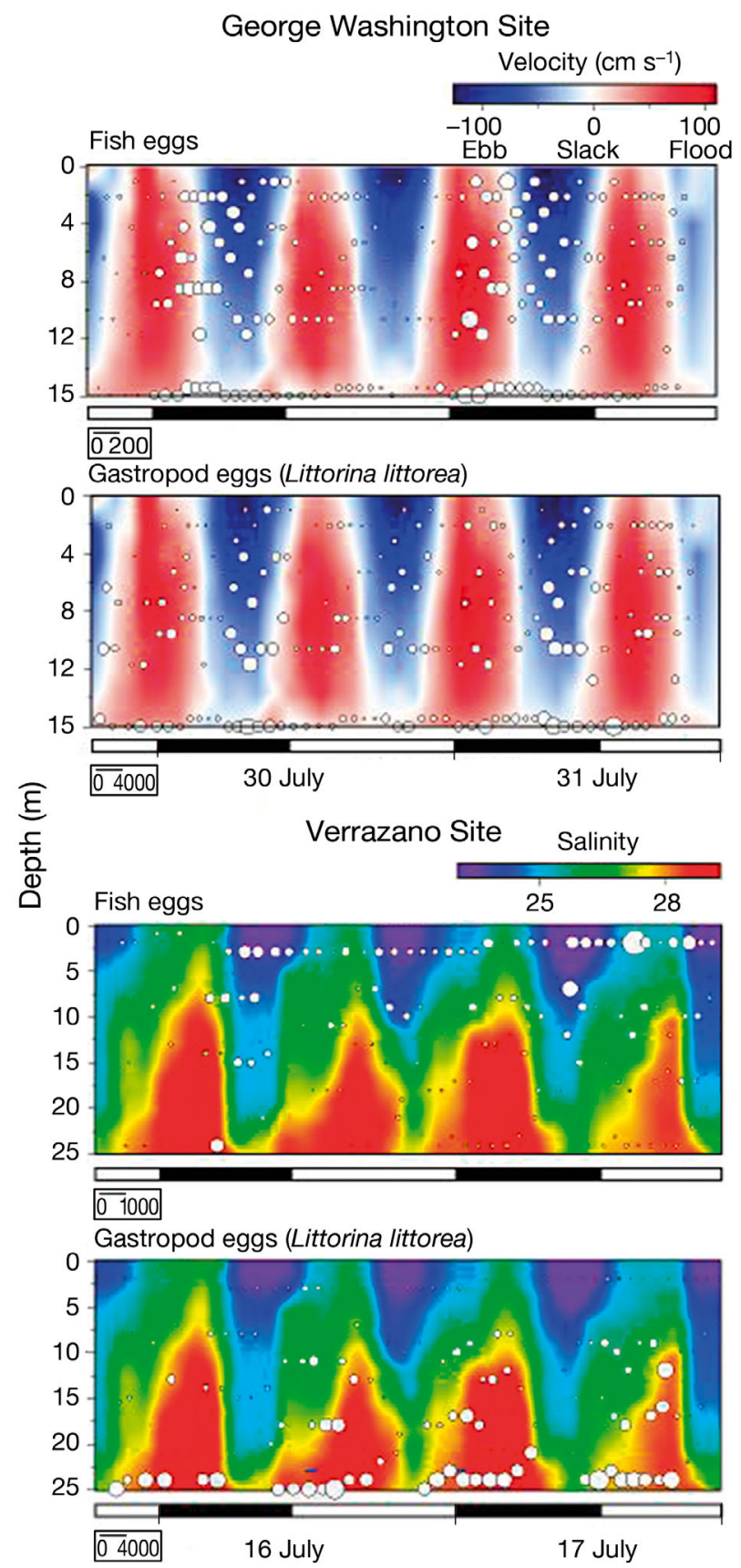

Fig. 7. Anchoa mitchilli and Littorina littorea. Vertical distribution and abundance of fish and snail eggs relative to current velocity (shown in Fig. 3) at the George Washington bridge site and salinity (shown in Fig. 4) at the Verrazano Narrows site in the Hudson River estuary during $48 \mathrm{~h}$ studies conducted from 29 to 31 July and from 15 to 17 July 1992 for velocity and salinity, respectively. The sizes of filled circles represent the abundances of eggs during each sampling period; see scale below the lower left corner of each plot for the conversion of circle diameter to abundance (eggs $\mathrm{m}^{-3}$ ). Open and solid bars below the horizontal axes represent daylight and darkness, respectively. Negative current velocities indicate seaward flow, positive values indicate upstream flow, and velocities between -30 and $+30 \mathrm{~cm} \mathrm{~s}^{-1}$ represent slack water (white). The water column is $1 \mathrm{~m}$ deeper than shown

\section{George Washington Site}

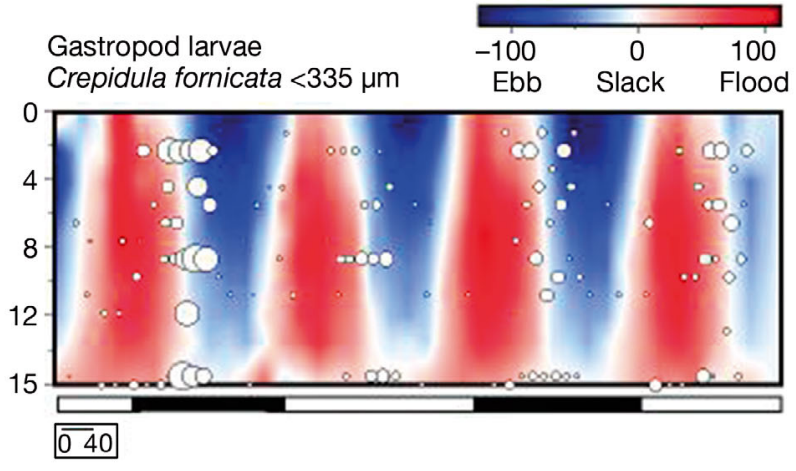

Crepidula fornicata $>335 \mu \mathrm{m}$
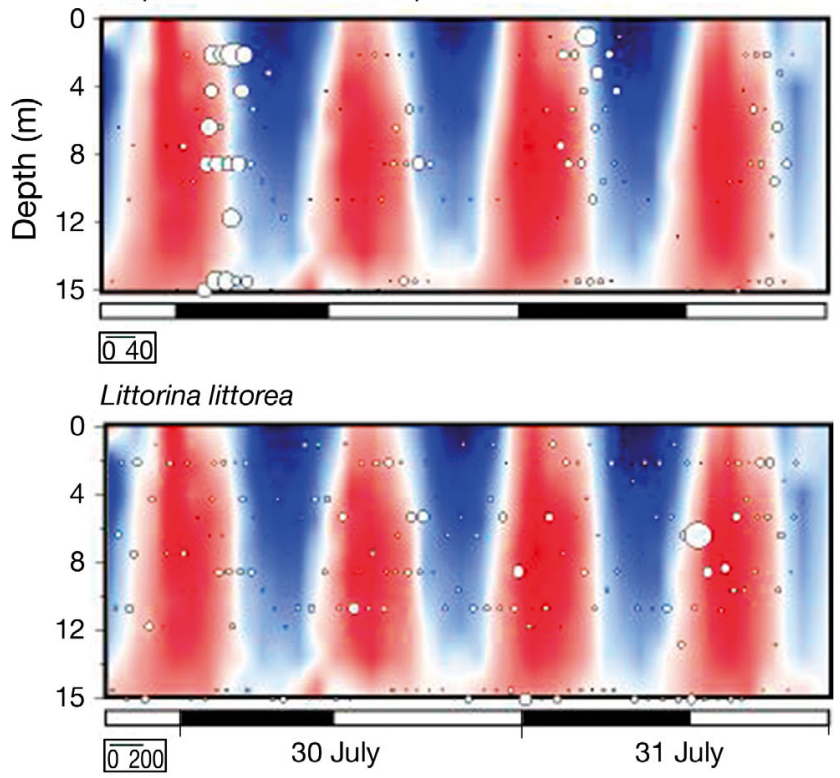

Fig. 8. Crepidula fornicata and Littorina littorea. Vertical distribution and abundance of gastropod larvae relative to current velocity at the George Washington bridge site in the Hudson River estuary for $48 \mathrm{~h}$ from 29 to 31 July 1992. See Fig. 7 for details

Rhithropanopeus harrisii larvae were abundant during daytime flood tides at the GW site (Figs. 5 \& 10) and were uncommon downstream at the VZ site (Tables S1-S3). Consequently, water advected by stronger nocturnal flood tides from farther downstream would have contained fewer larvae than water advected by weaker daytime flood tides from nearby locations. In addition, first-stage larvae were most abundant during the daytime throughout the study period. These larvae were most abundant near the onset of flood tides, which only occurred during daylight, and hence they were more abundant during the daytime than nighttime. First-stage larvae also were more abundant at the surface during slack after flood tides in the daytime than they were at 

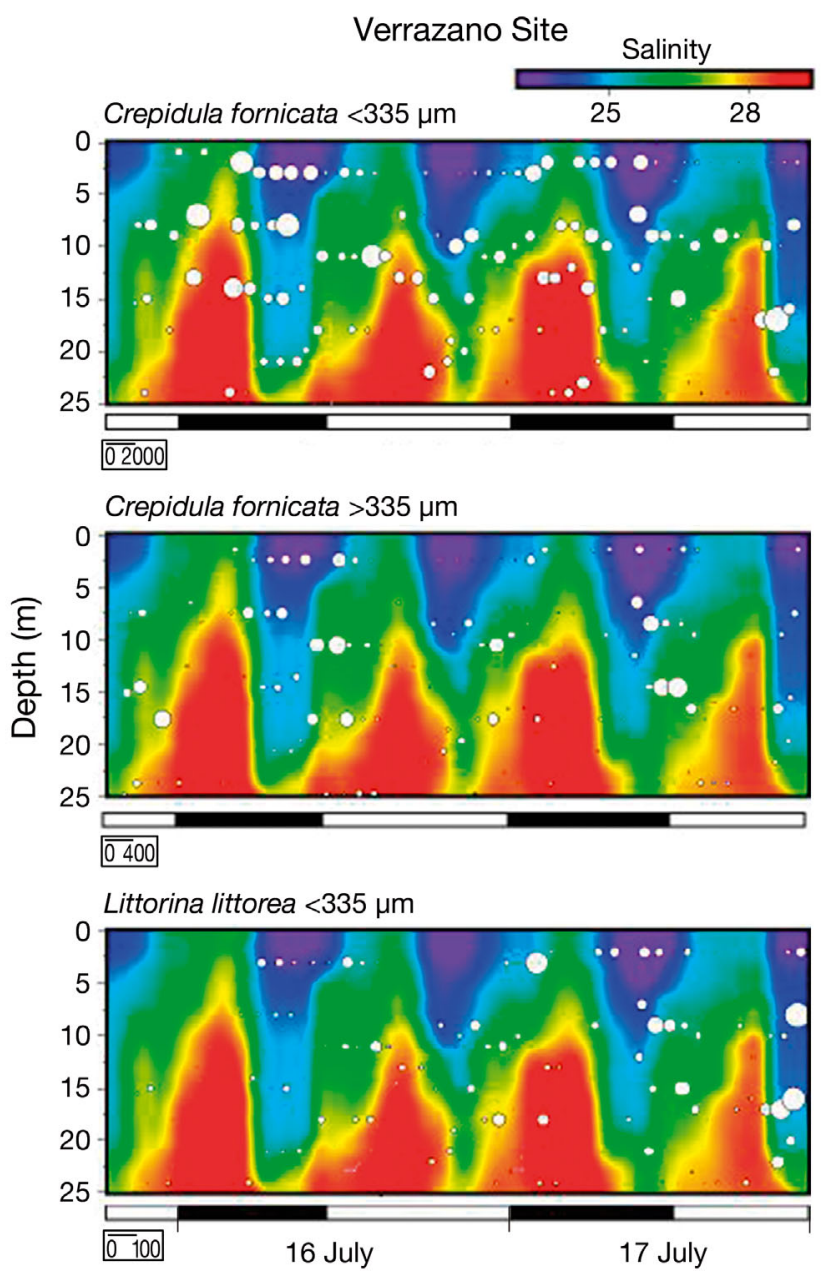

Fig. 9. Crepidula fornicata and Littorina littorea. Vertical distribution and abundance of gastropod larvae relative to salinity at the Verrazano Narrows site in the Hudson River estuary for $48 \mathrm{~h}$ from 15 to 17 July 1992. See Fig. 7 for details

night. Maximal flood currents occurred toward the end of flood tides at night, and more larvae may have been mixed lower in the water column than during flood tides in the daytime. Thus, this species appeared to maintain position in the mid- to upper water column, but diel, tidal, and ontogenetic vertical migrations were not evident.

Although Rhithropanopeus harrisii larvae were uncommon at the VZ site, larvae of another mud crab, Dyspanopeus sayi, were abundant in these saltier waters (Table S3), indicating that the lower bound for $R$. harrisii larvae and the upper bound for $D$. sayi larvae occurred between the 2 study sites. Larvae of both species were retained in the estuary because all 4 larval stages were collected.

All 4 instars of Dyspanopeus sayi were most abundant in the warm upper water column and at night
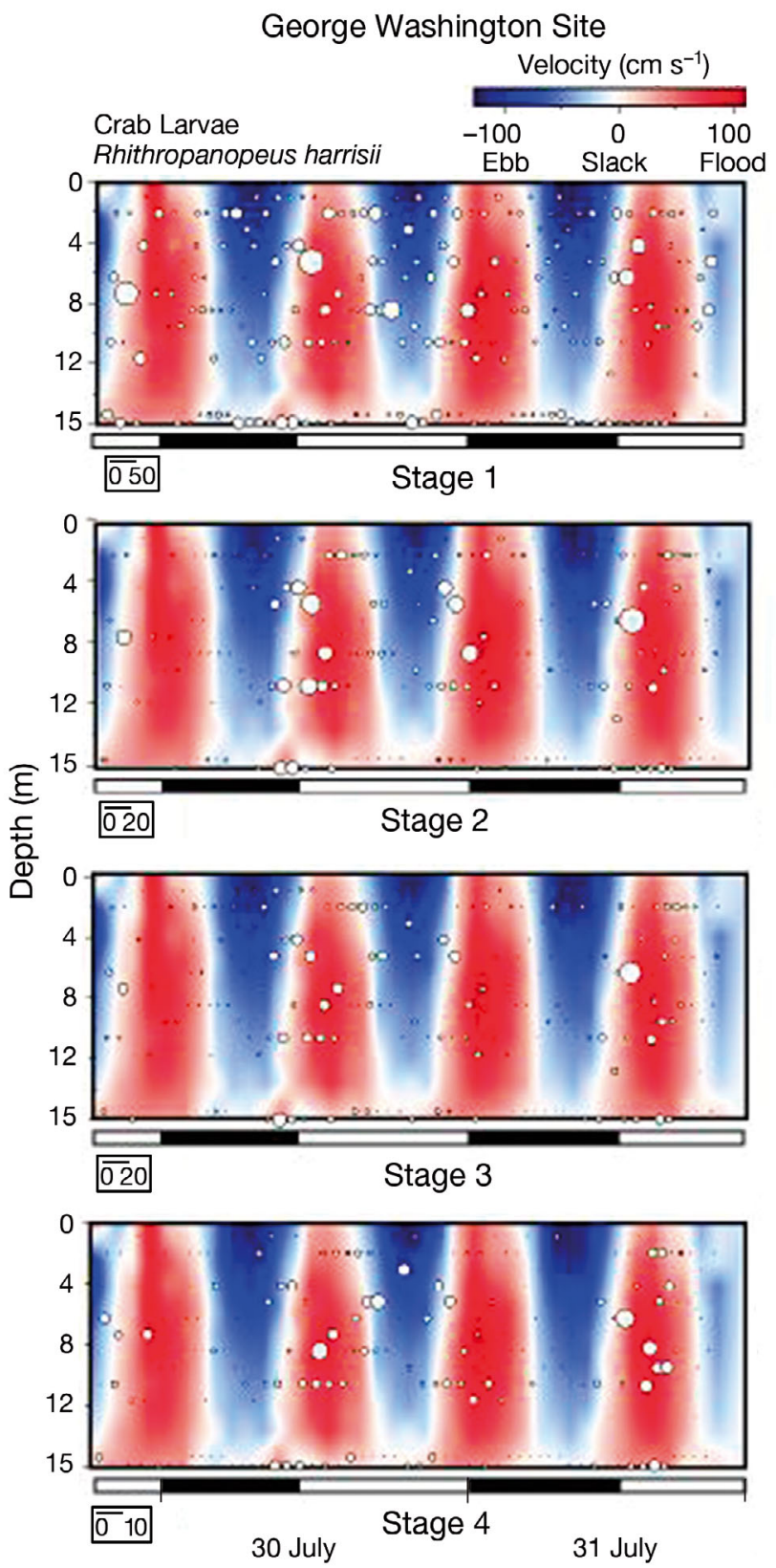

Fig. 10. Rhithropanopeus harrisii. Vertical distribution and abundance of crab larvae relative to current velocity at the George Washington bridge site in the Hudson River estuary for $48 \mathrm{~h}$ from 29 to 31 July 1992. See Fig. 7 for details

(Figs. 6 \& 11; Tables S1 \& S2). As development progressed, the proportion of larvae occurring from late flood tides through early ebb tides increased relative to the rest of the tidal cycle. This trend became significant late in development (third and fourth stages) because increasingly few larvae remained upstream of the study site to be transported there by ebb currents. Larvae increasingly arrived at the study site toward the end of flood tides from far 


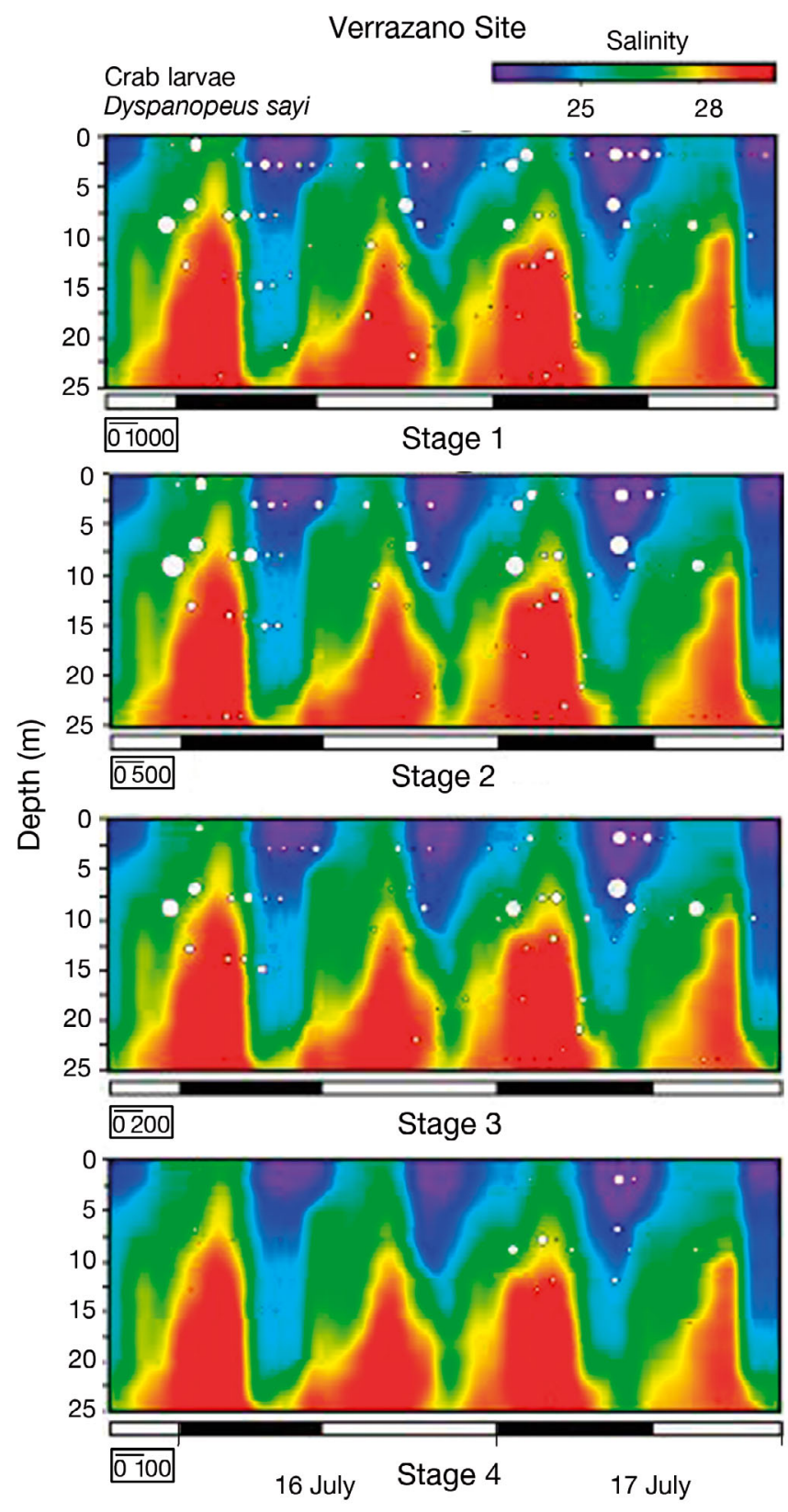

Fig. 11. Dyspanopeus sayi. Vertical distribution and abundance of crab larvae relative to salinity at the Verrazano Narrows site in the Hudson River estuary for $48 \mathrm{~h}$ from 15 to 17 July 1992. See Fig. 7 for details

downstream and then were swept back downstream by early ebb currents. This was also suggested by the increasing abundance of larvae during strong nocturnal flood tides, which transported larvae to the study site from farther downstream than did weaker daytime flood tides. This trend became significant for the last larval stage, which presumably occurred farther downstream than did earlier instars. The associ-
George Washington Site
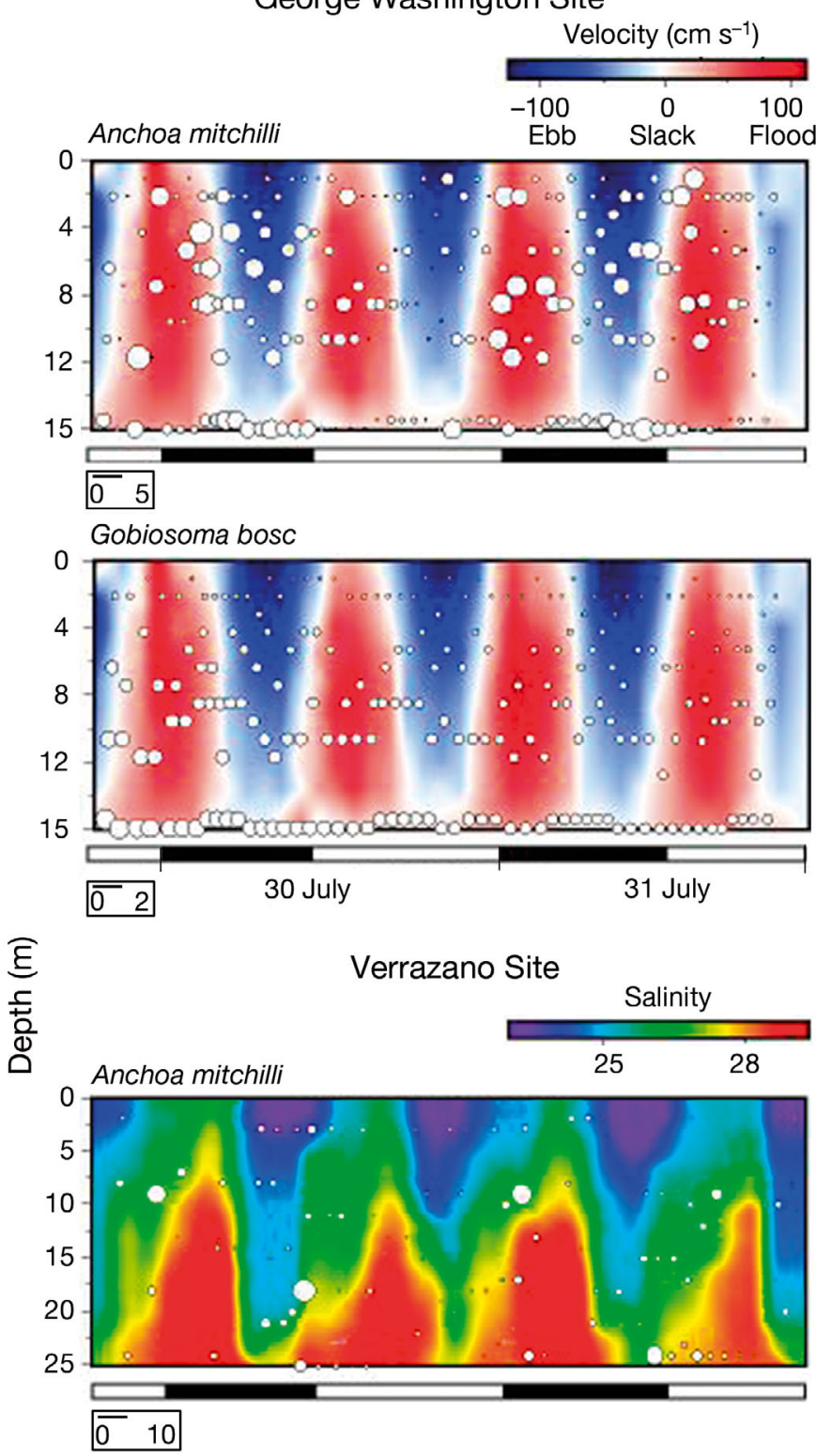

\section{Gobiosoma bosc}

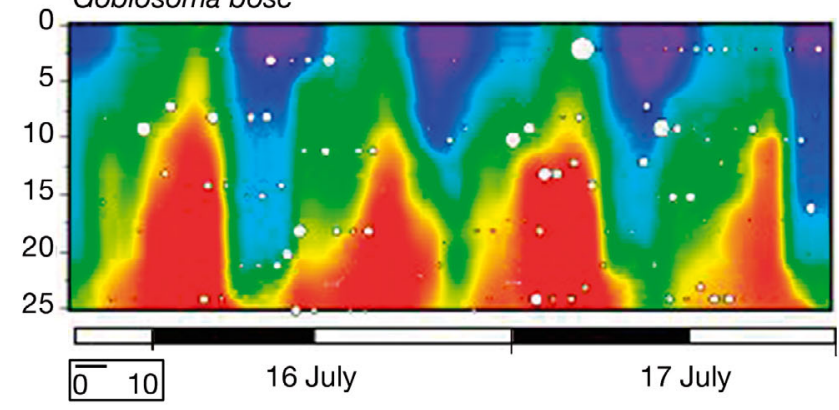

Fig. 12. Anchoa mitchilli and Gobiosoma bosc. Vertical distribution and abundance of fish larvae relative to current velocity at the George Washington bridge site and salinity at the Verrazano Narrows site in the Hudson River estuary for $48 \mathrm{~h}$ from 29 to 31 July and from 15 to 17 July 1992, respectively. See Fig. 7 for details 
ation of third-stage larvae with high-salinity flood currents further indicates that these larvae were primarily transported to the study site from far downstream. The last 2 larval stages avoided surface waters in the daytime.

\section{Fish larvae}

Tidal and diel vertical migrations were not apparent for Anchoa mitchilli larvae at the GW site (Figs. 5 \& 12; Tables $\mathrm{S} 1$ \& $\mathrm{S} 2$ ). These larvae primarily occurred in the mid- to upper water column during flood tide, and apparently were mixed throughout the water column by ebb currents. They were particularly abundant from late ebb to early flood tides at night, suggesting that most of them were transported there from far upstream and then were returned upstream by flood currents together with larvae from just downstream of the study site. Larvae were not related to any physical factors that were associated with the tidal cycle.

Although tidal and diel vertical migrations were not apparent at the GW site, they were evident at the VZ site (Figs. 6 \& 12; Tables S1-S3). Anchoa mitchilli larvae were most abundant at mid-depth from slack after ebb through flood tides at night, and they were least abundant and lower in the water column from slack after flood through ebb tides in the daytime. Hence, A. mitchilli larvae were associated with strong flood currents and stratified waters and may have been transported upstream. These larvae were more abundant at the GW site than they were $2 \mathrm{wk}$ later at the VZ site.

The abundance of Gobiosoma bosc larvae gradually increased from the surface to the bottom of the water column, occurring in cool saline waters at the GW site (Figs. 5 \& 12; Tables S1-S3). Most larvae occurred from slack after ebb to early flood tides at night, suggesting that, like Anchoa mitchilli larvae, they were delivered to this site from upstream by ebb currents and returned back upstream together with larvae from nearby locations downstream by flood currents. These small preflexion larvae were more than twice as abundant 2 wk later at the VZ than the GW site.

Like Anchoa mitchilli, Gobiosoma bosc larvae appeared to undertake tidal and diel vertical migrations at the VZ site (Figs. 6 \& 12; Tables S1 \& S2). They were most abundant at mid-depth in stratified waters from flood through slack after flood tide at night, and they occurred lower in the water column from ebb through slack after ebb tide, especially during the daytime.

\section{DISCUSSION}

\section{Spawning, mixing, and passive transport of eggs}

Different physical dynamics at the 2 study sites affected the vertical distributions and transport of eggs. Anchoa mitchilli eggs previously have been shown to occur throughout the water column at low salinities and in surface currents at high salinities (Matarese \& Sandknop 1983), where faster downstream transport occurs. Spawning during strong nocturnal ebb tides (resulting from the diurnal inequality in the tides), further expedited seaward transport, as has been previously found for many estuarine and marine invertebrates and fishes (Johannes 1978, Morgan 1995, Thurman 2004). Nocturnal spawning by A. mitchilli has previously been reported (Wang \& Kernehan 1979, Ferraro 1980, Matarese \& Sandknop 1983), but this is the first indication that spawning is synchronized with the tidal cycle.

Unlike fish eggs, negatively buoyant Littorina littorea eggs were suspended from the substrate by flood and ebb currents into residual bottom currents transporting them upstream at $19 \mathrm{~cm} \mathrm{~s}^{-1}$ (Heilman 1995). At the deeper VZ site, they were suspended from the substrate only by flood currents, which normally would be expected to result in faster upstream transport. However, during our study, residual flow unexpectedly was seaward throughout the water column due to the barotropic response to the change in sea level (Heilman 1995, Lerczak et al. 2006). Peak spawning by $L$. littorea occurs during nocturnal spring tides, resulting in the high nocturnal abundances of eggs at the GW site (Fish 1979, Todd \& Laverack 1991).

\section{Depth regulation and larval transport}

Although different buoyancies passively segregated fish and snail eggs into different parts of the water column, negatively buoyant larvae generally remained in discrete water masses by overcoming mixing by tidal currents. However, the capacity to regulate depth depended on swimming capability and the degree of mixing (Raby et al. 1994, Hsieh et al. 2010, Tilburg et al. 2010). In the predominantly mixed tidal environment at the GW site, larvae maintained depth preferences except during maximum mixing of mid-ebb or mid-flood tides. Only small, weakly swimming gastropod larvae (Crepidula fornicata, Littorina littorea) showed limited ability to re- 
gulate depth at this site; they were mixed throughout the water column together with negatively buoyant $L$. littorea eggs, although $L$. littorea larvae did undertake diel vertical migrations. The difficulty of regulating depth in this turbulent environment was most clearly indicated by the inability of larvae to complete vertical migrations that were evident at the VZ site or elsewhere (Bousfield 1955, Wang \& Kernehan 1979, Cronin \& Forward 1986, Raby et al. 1994, Hagan \& Able 2008). At the VZ site, larvae of all but 1 species (C. fornicata) undertook diel vertical migrations, and larvae of both fishes were discovered to undertake tidal vertical migrations. Dyspanoeus sayi larvae were not able to complete previously described tidal vertical migrations at this site (Bousfield 1955, Schell 1996, Hovel \& Morgan 1997), but vertical migrations may have been detected for more species at the VZ site, had a lateral eddy not formed during the last $8 \mathrm{~h}$ of the sampling period, as has previously been observed (Chant \& Wilson 1997). As expected, ontogenetic vertical migrations were not apparent for any of the 3 study species for which early and late larval stages were identified (Cronin \& Forward 1979, Cronin 1982, Schell 1996).

Larvae completed development in the estuary even without undertaking tidal vertical migrations (Chen et al. 1997) by primarily occurring at mid-depth near the level of no net flow ( 0 residual velocity). Larvae of 3 invertebrates and the 2 fish species arrived on flood tides in intruding cold saline bottom water (Schultz et al. 2003, Dong et al. 2007, Islam et al. 2007) and rose until the pycnocline and velocity formed at middepth. Peak concentrations of larvae were transported upstream at maximal speeds compensating for downstream displacement during ebb tides. The depth of the pycnocline and velocity jet were shallower $(6 \mathrm{~m})$ at the GW than VZ site $(12 \mathrm{~m})$, and the lack of consistent associations with any physical variable between study sites and among species indicates that larvae were neither remaining in water masses of preferred salinity or temperature, nor trapped for long below the pycnocline in the velocity jet. Instead, interspecific depth preferences were evident with larvae regulating depth best at the VZ site and around slack tides due to reduced mixing. Interspecific depth preferences based on differing responses to gravity, hydrostatic pressure, light, and turbulence have been well described in the laboratory (Forward 1989, Young 1995, Welch et al. 1999, Kingsford et al. 2002, Fuchs et al. 2004).

Interspecific differences in vertical distributions of eggs and larvae resulted in differential larval transport. Most of the study species release eggs and lar- vae in the lower estuary and were transported upstream to the GW site by flood currents, whereas Rhithropanopeus harrisii larvae primarily are released in brackish waters and were transported downstream to the GW site by ebb currents (Bousfield 1955, Sandifer 1975, Cronin 1982). In contrast, larvae of all species were common throughout the tidal cycle at the VZ site arriving from both upstream and downstream locations, although more snail and $R$. harrisii larvae arrived on ebb tides from upstream and more Dyspanopeus sayi and fish larvae arrived from flood tides from downstream. The fish larvae develop entirely (Gobiosoma bosc) or primarily ( $A n$ choa mitchilli) in the estuary (Able et al. 2006) and move upstream during development (Massmann et al. 1963, Wang \& Kernehan 1979, Schultz et al. 2003, 2005) by undertaking tidal vertical migrations, as previously observed for other fishes (Rowe \& Epifanio 1994, Forward et al. 1998, Jager 1999, Hare et al. 2005). Rates of upstream larval transport may be greater during neap tide and less in the shallow margins of the estuary (Jager 2002, Schultz et al. 2003).

Conceivably, periodic larval migrations to the top or bottom $1.5 \mathrm{~m}$ of the water column also could account for the observed oscillations in larval abundance. In this scenario, larvae periodically aggregate in surface or bottom boundary layers (where sampling was not conducted), and then rapidly swim the full extent of the water column during a single $45 \mathrm{~min}$ sampling cycle. In this way, larvae could largely disappear from the water column during 1 sampling cycle and reappear in all 4 depth bins during the next cycle. Such behavior has been proposed for latestage larvae of oysters and postlarvae of barnacles, crabs, and shrimp that may settle onto the substrate during ebb tides and rise during flood tides (Carriker 1951, Rothlisberg et al. 1995, Christy \& Morgan 1998). However, this scenario was not found to be the case for pediveligers previously (Baker \& Mann 2003), and is highly unlikely to be the case in the present study. To elude capture, larvae would have to remain in the bottom $1.5 \mathrm{~m}$ of the water column during most of the tidal cycle and then swim throughout the water column during slack after flood tide. To accomplish this feat at the GW site, even weakly swimming snail larvae would have to overcome maximal turbulence from an intruding bottom front and remain on the substrate for 5 to $6 \mathrm{~h}$ while snail eggs mixed high into the water column. Furthermore, invertebrate larvae were not able to complete previously described tidal vertical migrations at either site. Therefore, the strikingly well defined and regular appearance of larvae was due to advection of larvae 
to the study sites rather than vertical migration between the bottom boundary layer and the water column.

\section{CONCLUSIONS}

Our comparative hypothesis testing approach combined with intensive hourly sampling over consecutive diel and tidal cycles throughout the water column yielded important insights into the relative contributions of behavior and hydrodynamics to larval transport. Using eggs of different buoyancies as passive tracers indicated that larvae regulated their position in the water column. Contrasts among diverse species with different swimming capabilities and sites with different levels of mixing revealed considerable variation in the abilities of larvae to regulate depth. Larvae regulated depth even at the well-mixed site, although weakly swimming gastropod larvae were least able to do so, and all species regulated depth more effectively at the partially stratified site. Contrasting larval abundances and distributions at the 2 study sites with known adult distributions revealed the consequences of larval behavior, turbulent mixing, and advection on larval transport. Regardless of swimming ability, larvae of all species were retained in the estuary by occurring near the level of no net motion, even without completing tidal vertical migrations. High-frequency sampling revealed previously unknown tidal rhythms in spawning by Anchoa mitchilli and tidal vertical migration by both $A$. mitchilli and Gobiosoma bosc.

Although investigators often conclude that plankton distributions are stochastic and unpredictable, displaying continuous records of larval distributions over a $2 \mathrm{~d}$ period revealed strong patterns, even in a highly turbulent tidal environment. Striking patterns were repeated from one day to the next for a variety of species with different swimming capabilities. A well-defined pattern also was evident from one larval stage to the next for all 3 species for which ontogenetic vertical distributions were examined. Moreover, similar patterns were observed for both species of crabs and fishes. Thus, larval behavior interacts with local hydrodynamics in consistent ways, but continuous records of larval distributions are needed to detect the patterns and understand the underlying processes. Further improvements to sampling designs might include finer profiling of the water column, sampling for several consecutive days to permit time-series analysis, sampling sites concurrently, and using a complementary Lagrangian strategy of repeatedly sampling the same water mass. Until a temporally and spatially exhaustive sampling strategy is coupled with other approaches, such as individual based and numerical models (North et al. 2008, Kim et al. 2010), larval behavior mimics (Wolcott 1995), natural elemental tags (Levin 1990, Anastasia et al. 1998), population genetics (Projecto-Garcia et al. 2010), or parentage analysis (Berumen et al. 2012), the roles of behavioral and physical processes in larval transport will not be fully resolved.

Acknowledgements. We thank J. Anastasia, T. Bridges, L. Heilman, K. Hovel, C. Lobue, A. Matthews, and J. Schell for assisting in the field; J. Anastasia, K. Hovel, and A. Matthews for assisting with processing plankton samples; and L. Heilman and B. Connolly for assisting with data analysis and presentation. We thank G. Lima and J. Hare for confirming identifications of gastropod and fish larvae, respectively. We also thank the crew of the RV 'Onrust,' B. Zielenski, and M. Wiggins. Helpful comments on earlier versions of the manuscript were provided by S. McAfee and B. Cowen. Funding was provided by the Hudson River Foundation (no. 01091A). This manuscript is dedicated to the memory of Holly Kunze.

\section{LITERATURE CITED}

Able KW, Fahay MP, Witting DA, McBride RS, Hagan SM (2006) Fish settlement in the ocean vs. estuary: comparison of pelagic larval and settled juvenile composition and abundance from southern New Jersey, USA. Estuar Coast Shelf Sci 66:280-290

Abood K (1977) Evaluation of circulation in partially stratified estuaries as typified by the Hudson River. PhD dissertation, Rutgers University, Newark, NJ

Alifierakis NS, Berry AJ (1980) Rhythmic egg release in Littorina littorea (Mollusca: Gastropoda). J Zool 190: 297-307

Anastasia JC, Morgan SG, Fisher NS (1998) Tagging crustacean larvae: assimilation and retention of trace elements. Limnol Oceanogr 43:362-368

Baker P, Mann R (2003) Late stage bivalve larvae in a wellmixed estuary are not inert particles. Estuaries 26:837-845

Bauer B, Fioroni P, Ide I, Liebe S, Oehlmann J, Stroben E, Watermann B (1995) TBT effects in the female genital system of Littorina littorea: a possible indicator of tributylin pollution. Hydrobiologia 309:15-27

> Berumen ML, Almany GR, Planes S, Jones GP, SaenzAgudelo P, Thorrold SR (2012) Persistence of self-recruitment and patterns of larval connectivity in a marine protected area network. Ecol Evol 2:444-452

Blaxter JHS (1969) Development: eggs and larvae. In: Hoar WS, Randall DJ (eds) Fish physiology, Vol 3. Academic Press, New York, NY, p 177-252

Bousfield EL (1955) Ecological control of the occurrence of barnacles in the Miramichi estuary. Bull Natl Mus Can 137:1-69

Breitburg DL (1989) Demersal schooling prior to settlement of larvae of the naked goby. Environ Biol Fishes 26:97-103

Carriker MR (1951) Ecological observations on the distribution of oyster larvae in New Jersey estuaries. Ecol Monogr 21:19-38

- Chant RJ, Wilson RE (1997) Secondary circulation in a highly stratified estuary. J Geophys Res 102:23207-23215 Chant RJ, Wilson RE (2000) Internal hydraulics and mixing 
in a highly stratified estuary. J Geophys Res 105:1421514222

Chen YH, Shaw PT, Wolcott TG (1997) Enhancing estuarine retention of planktonic larvae by tidal currents. Estuar Coast Shelf Sci 45:525-533

Chia FS, Buckland-Nicks J, Young CM (1984) Locomotion of marine invertebrate larvae: a review. Can J Zool 62: 1205-1222

Chipperfield PNJ (1951) The breeding of Crepidula fornicata (L.) in the River Blackwater, Essex. J Mar Biol Assoc UK 30:49-70

Christy JH, Morgan SG (1998) Estuarine immigration by crab postlarvae: mechanisms, reliability and adaptive significance. Mar Ecol Prog Ser 174:51-65

Cronin TW (1982) Estuarine retention of larvae of the crab Rhithropanopeus harrisii. Estuar Coast Shelf Sci 15: 207-220

> Cronin TW, Forward RB Jr (1979) Tidal vertical migration: an endogenous rhythm in estuarine crab larvae. Science 205:1020-1022

Cronin TW, Forward RB Jr (1986) Vertical migration cycles of crab larvae and their role in larval dispersal. Bull Mar Sci 39:192-201

Dahlberg MD, Conyers JC (1973) An ecological study of Gobiosoma bosci and G. ginsburgi on the Georgia coast. Fish Bull 71:279-287

DeVries MC, Forward RB Jr (1989) Rhythms of larval release of the sublittoral crab Neopanope sayi and the supralittoral crab Sesarma cinereum (Decapoda: Brachyura). Mar Biol 100:241-248

DeVries MC, Tankersley RA, Forward RB Jr, Kirby-Smith WW, Luettich RA Jr (1994) Abundance of estuarine crab larvae is associated with tidal hydrologic variables. Mar Biol 118:403-413

DeWolf P (1973) Ecological observations on the mechanisms of dispersal of barnacle larvae during planktonic life and settling. Neth J Sea Res 6:1-129

Dong L, Su J, Deng J, Chen Q (2007) The importance of estuarine gravitational circulation in the early life of the Bohai penaeid prawn. J Mar Syst 67:253-262

Dovel WL (1981) Ichthyoplankton of the lower Hudson estuary, New York. NY Fish Game J 28:21-39

Epifanio CE (1988) Transport of invertebrate larvae between estuaries and the continental shelf. Am Fish Soc Symp 3: 104-114

Fahay MP (1983) Guide to the early stages of marine fishes occurring in the Western North Atlantic Ocean, Cape Hatteras to the Southern Scotian Shelf. J NW Atl Fish Sci $4: 1-423$

Ferraro SP (1980) Daily time of spawning of 12 fishes in the Peconic Bays, New York. Fish Bull 78:455-464

Fish JD (1979) The rhythmic spawning behavior of Littorina littorea. J Molluscan Stud 45:172-177

Forward RB Jr (1989) Depth regulation of larval marine decapod crustaceans: test of a hypothesis. Mar Biol 102: 195-201

Forward RB Jr, Tankersley RA (2001) Selective tidal-stream transport of marine animals. Oceanogr Mar Biol Annu Rev 39:305-353

Forward RB Jr, Tankersley RA, Reinsela KA (1998) Selective tidal stream transport of spot (Leistomus xanthurus Lacepede) and pinfish [Lagodon rhomboides (Linnaeus)] larvae: contribution of circatidal rhythms in activity. J Exp Mar Biol Ecol 226:19-32

Fretter V, Graham A (1962) British prosobranch molluscs. The Ray Society, London

- Fuchs HL, Mullineaux LS, Solow A (2004) Sinking behavior of gastropod larvae (Ilyanassa obsoleta) in turbulence. Limnol Oceanogr 49:1937-1945

Geyer WR, Farmer DM (1989) Tide-induced variations in the dynamics of a salt wedge estuary. J Phys Oceanogr 19: 1060-1072

Hagan SM, Able KW (2008) Diel variation in the pelagic fish assemblage in a temperate estuary. Estuar Coast 31: $33-42$

> Hare JA, Thorrold S, Walsh H, Reiss C, Valle-Levinson A, Jones C (2005) Biophysical mechanisms of larval fish ingress into Chesapeake Bay. Mar Ecol Prog Ser 303: 295-310

Hardwick-Witman MN, Mathieson AC (1983) Intertidal macroalgae and macroinvertebrates: seasonal and spatial abundance patterns along an estuarine gradient. Estuar Coast Shelf Sci 16:113-129

Heilman L (1995) Physical factors regulating larval transport in the Hudson River estuary. MSc thesis, State University of New York, Stony Brook, NY

Houde ED, Zastrow CE (1991) Anchoa mitchilli. In: Funderburk SL, Mihurisky JA, Jordan SJ, Riley JD (eds) Habitat requirements for Chesapeake Bay living resources. Living Resources Subcommittee, Chesapeake Bay Program, Annapolis, MD, p 8.1-8.11

> Hovel KA, Morgan SG (1997) Planktivory as a selective force for reproductive synchrony and larval migration. Mar Ecol Prog Ser 157:79-95

Hsieh HL, Fan LF, Chen CP, Wu, Liu WC (2010) Effects of semidiurnal tidal circulation on the distribution of holoand meroplankton in a subtropical estuary. J Plankton Res 32:829-841

Hunkins K (1981) Salt dispersion in the Hudson Estuary. J Phys Oceanogr 11:729-738

Hunter JR (1981) Feeding ecology and predation of marine fish larvae. In: Lasker R (ed) Marine fish larvae: morphology, ecology and relation to fisheries. Washington Sea Grant Program, University of Washington, Seattle, WA, p 34-77

Islam S, Hibino M, Tanaka M (2007) Tidal and diurnal variations in larval fish abundance in an estuarine inlet in Ariake Bay, Japan: implication for selective tidal stream transport. Ecol Res 22:165-171

Jager Z (1999) Selective tidal stream transport of flounder larvae (Platichthys flesus L.) in the Dollard (Ems Estuary). Estuar Coast Shelf Sci 49:347-362

Jager Z (2002) Across-channel distribution of flounder larvae (Platichthys flesus L.) in the Eems-Dollard estuary and its effects on larval transport estimates. ICES J Mar Sci 59:1187-1198

Jay DA, Smith JD (1990) Residual circulation in shallow estuaries. 1. Highly stratified, narrow estuaries. J Geophys Res 95:711-731

Johannes RE (1978) Reproductive strategies of coastal marine fishes in the tropics. Environ Biol Fishes 3:65-84

Kim CK, Park JK, Powers SP, Graham WM, Bayha KM (2010) Oyster larval transport in coastal Alabama: dominance of physical transport over biological behavior in a shallow estuary. J Geophys Res 115:C10019 doi: 10.1029/2010JC006115

Kingsford MJ, Leis J, Shanks A, Lindeman K, Morgan S, Pineda J (2002) Sensory environments, larval abilities and local self-recruitment. Bull Mar Sci 70:309-340

Lerczak JA, Geyer WR, Chant RJ (2006) Mechanisms driving the time-dependent salt flux in a partially stratified estuary. J Phys Oceanogr 36:2296-2311

Levin LA (1990) A review of methods for labeling and tracking marine invertebrate larvae. Ophelia 32:115-144 
Lima GN (1987) Larval development of marine prosobranch gastropods: ecological and paleontological implications. $\mathrm{PhD}$ dissertation, Rutgers University, Newark, NJ

MacCready P, Geyer WR (2010) Advances in estuarine physics. Annu Rev Mar Sci 2:35-58

Massmann WH, Norcross JJ, Joseph EB (1963) Distribution of larvae of the naked goby, Gobiosoma bosci, in the York River. Chesap Sci 4:120-125

Matarese AC, Sandknop WM (1983) Identification of fish eggs in ontogeny and systematics of fishes; based on an international symposium dedicated to the memory of Elbert Halver Ahlstron. Spec Publ 1. American Society of Ichthyologists and Herpetologists, Miami, FL, p 159-584

McCleave JD, Wippelhauser GS (1987) Behavioral aspects of selective tidal stream transport in juvenile American eel (Anguilla rostrata). Am Fish Soc Symp 1:138-150

Metaxas A (2001) Behaviour in flow: perspectives on the distribution and dispersion of meroplanktonic larvae in the water column. Can J Fish Aquat Sci 58:86-98

Morgan SG (1995) The timing of larval release. In: McEdward L (ed) Ecology of marine invertebrate larvae. CRC, Boca Raton, FL, p 157-192

Morgan SG (2001) The larval ecology of marine communities. In: Bertness MD, Gaines SD, Hay ME (eds) The ecology of marine communities. Sinauer Associates, New York, NY, p 158-170

Morgan SG (2005) Larval migration between the Hudson River estuary and New York Bight. In: Levinton JS, Waldman JR (eds) The Hudson River estuary. Cambridge University Press, Cambridge, p 157-170

Naylor E (2006) Orientation and navigation in coastal and estuarine zooplankton. Mar Freshw Behav Physiol 39: $13-24$

Newell GE, Newell RC (1973) Marine plankton: a practical guide. Hutchinson Educational, London

North EW, Schlag Z, Hood RR, Li M, Zhong L, Gross T, Kennedy VS (2008) Vertical swimming behavior influences the dispersal of simulated oyster larvae in a coupled particle-tracking and hydrodynamic model of Chesapeake Bay. Mar Ecol Prog Ser 359:99-115

Parker JH, Duedall IW, O'Connors HB, Wilson RE (1976) The role of Raritan Bay as a source of ammonium and chlorophyll a for the New York Bight Apex. Limnol Oceanogr Spec Symp 2:212-219

> Pechenik JA (1984) The relationship between temperature, growth rate and duration of planktonic life for larvae of the gastropod C. fornicata. J Exp Mar Biol Ecol 74: 241-257

> Pechenik JA, Lima GM (1984) Relationship between growth, differentiation and length of larval life for individually reared larvae of the marine gastropod, C. fornicata. Biol Bull (Woods Hole) 166:537-549

Peters H (1995) Observations of stratified turbulent mixing in an estuary: neap-to-spring variations during high river flow. Estuar Coast Shelf Sci 27:1-24

Projecto-Garcia J, Cabral H, Schubart CD (2010) High regional differentiation in a North American crab species throughout its native range and invaded European waters: a phylogeographic analysis. Biol Invasions 12: 253-263

> Queiroga H, Blanton J (2005) Interactions between behaviour and physical forcing in the control of horizontal transport of decapod crustacean larvae. Adv Mar Biol 47: 107-214

Raby D, Lagadeuc Y, Dodson JJ, Mingelbier M (1994) Relationship between feeding and vertical distribution of bivalve larvae in stratified and mixed waters. Mar Ecol
Prog Ser 103:275-284

Rothlisberg PC, Church JA, Fandry CB (1995) A mechanism for near-shore concentration and estuarine recruitment of postlarval Penaeus plebejus Hess (Decapoda, Penaeidae). Estuar Coast Shelf Sci 40:115-138

Rowe PM, Epifanio CE (1994) Tidal stream transport of weakfish larvae in Delaware Bay, USA. Mar Ecol Prog Ser 110:105-114

Sandifer PA (1975) The role of pelagic larvae in recruitment to populations of adult decapod crustaceans in the York River estuary and adjacent lower Chesapeake Bay, Virginia. Estuar Coast Mar Sci 3:269-279

Schell J (1996) Variation in the timing of vertical swimming by crab larvae in two tidal regimes. MSc thesis, State University of New York, Stony Brook, NY

> Schultz ET, Lwiza KMM, Fencil MC, Martin JM (2003) Mechanisms promoting upriver transport of larvae of two fish species in the Hudson River estuary. Mar Ecol Prog Ser 251:263-277

Schultz ET, Young J, Martin JM, Lwiza KMM (2005) Tracking cohorts: analysis of migration in the early life stages of an estuarine fish. Estuaries 28:394-405

Strathmann RR, Hughes TP, Kuris AM, Lindeman KC, Morgan SG, Pandolfi JM, Warner RR (2002) Evolution of selfrecruitment and its consequences for marine populations. Bull Mar Sci 70:377-396

Thurman CL (2004) Unravelling the ecological significance of endogenous rhythms in intertidal crabs. Biol Rhythm Res 35:43-67

Tilburg CE, Seay JE, Bishop TD, Miller HL III, Meile C (2010) Distribution and retention of Petrolisthes armatus in a coastal plain estuary: the role of vertical movement in larval transport. Estuar Coast Shelf Sci 88:260-266

Todd CD, Laverack MS (1991) Coastal marine zooplankton. Cambridge University Press, Cambridge

Wang CS, Kernehan RJ (1979) Fishes of the Delaware estuaries: a guide to the early life histories. EA Communications, Ecological Analysts, Towson, MD, p 49-51

Welch JM, Forward RB Jr, Howd PA (1999) Behavioral responses of blue crab Callinectes sapidus postlarvae to turbulence: implications for selective tidal stream transport. Mar Ecol Prog Ser 179:135-143

- Wells HM (1965) Maryland records of the gastropod Littorina littorea with a discussion controlling its salinity distribution. Chesap Sci 6:38-42

Wheatland SB (1956) Oceanography of Long Island Sound, 1952-1954. VII. Pelagic fish eggs and larvae. Bull Bingham Oceanogr Collect 15:234-314

Williams AB (1984) Shrimps, lobsters and crabs of the Atlantic coast of the Eastern United States, Maine to Florida. Smithsonian Institution Press, Washington, DC

> Wolcott TG (1995) New options in physiological and behavioural ecology through multichannel telemetry. J Exp Mar Biol Ecol 193:257-275

Young CM (1986) Direct observations of field swimming behavior in larvae of the colonial ascidian Ecteinascidia turbinata. Bull Mar Sci 96:279-289

- Young CM (1990) Larval ecology of marine invertebrates: a sesquicentennial history. Ophelia 32:1-48

Young CM (1995) Behavior and locomotion during the dispersal phase of larval life. In: McEdward L (ed) Ecology of marine invertebrate larvae. CRC Press, Boca Raton, FL, p 249-277

Zastrow CE, Houde ED, Morin LG (1991) Spawning, fecundity, hatch-date frequency and young-of-the-year growth of bay anchovy Anchoa mitchilli in midChesapeake Bay. Mar Ecol Prog Ser 73:161-171 